\title{
Seaweed Reproduction and Harvest Rebound in Southcentral Alaska: Implications for Wild Stock Management
}

\author{
Brian P. Ulaski ${ }^{1} \cdot$ Brenda Konar $^{1} \cdot$ Edward O. Otis ${ }^{2}$ \\ Received: 7 October 2019 / Revised: 27 March 2020 / Accepted: 30 March 2020 / Published online: 12 May 2020 \\ (C) The Author(s) 2020
}

\begin{abstract}
In Alaska, interest in harvesting seaweeds for personal use is growing and information on potential impacts of this activity on sustainability of wild populations is lacking. This study provides information on reproductive timing and size, standing crop, and harvest rebound of three commonly harvested seaweeds in Southcentral Alaska: the rockweed, Fucus distichus; the sugar kelp, Saccharina latissima; and the bull kelp, Nereocystis luetkeana. From March through October 2018, seaweeds were surveyed for reproductive status and harvested to determine how much biomass was available. From the harvests, individuals were measured to determine the size when they first become reproductive. Harvested plots were re-harvested to determine biomass regrowth after 2, 4, and 6 months. Fucus and Nereocystis were broadly reproductive over the summer, while Saccharina was not. The presence of reproductive Fucus and Nereocystis throughout the summer could buffer the impacts of late season harvesting. Depending on the species (e.g., Fucus), individuals that became reproductive at a larger size were associated with lower density and lower biomass areas with slower recovery. The amount of biomass available for harvest and the amount that regrew following a harvest were temporally variable but had spatial differences that were consistent throughout the summer. Regrowth following harvesting for all three species was generally low after only 2 months, but the amount of biomass after 6 months post-harvesting was sometimes comparable to non-harvested areas. This study demonstrated that to varying extents, seaweed harvesting may be sustainable if timing of reproduction, available biomass, and regrowth are all considered.
\end{abstract}

Keywords Seaweed $\cdot$ Kelp $\cdot$ Fucus $\cdot$ Harvest $\cdot$ Rebound $\cdot$ Reproduction

\section{Introduction}

Seaweeds provide important ecosystem services by offering habitat (Hamilton and Konar 2007), refuge (Miller et al. 2018), spawning substrate (Haegele et al. 1981), and nursery grounds (Eggertsen et al. 2017) for many commercial, subsistence, and ecologically important marine organisms.

Communicated by James Lovvorn

Electronic supplementary material The online version of this article (https://doi.org/10.1007/s12237-020-00740-1) contains supplementary material, which is available to authorized users.

Brian P. Ulaski

bpulaski2@alaska.edu

1 College of Fisheries and Ocean Sciences, University of Alaska Fairbanks, PO Box 757220, Fairbanks, AK 99775-7220, USA

2 Division of Commercial Fisheries, Alaska Department of Fish and Game, 3298 Douglas Pl, Homer, AK 99603-7942, USA
Seaweeds are also food for primary consumers, including a variety of fish and invertebrate species (Garcia-Esquivel and Felbeck 2009; Umezu et al. 2017; Ruz et al. 2018). When dislodged from their substrate, seaweeds may wash ashore, forming piles of wrack that link marine and terrestrial ecosystems (Dugan et al. 2003; Dugan and Hubbard 2010; Krumhansl and Scheibling 2012) and can also drift over long distances, providing a mechanism for fish and invertebrate dispersal while also subsidizing other offshore marine ecosystems (Hinojosa et al. 2011; Krumhansl and Scheibling 2012). In addition to their ecosystem services, seaweeds are used in mariculture or harvested from wild stocks (Pereira 2015). Traditionally, wild seaweeds have been harvested for personal use (i.e., artisanal, non-mechanized) and subsistence (i.e., traditional uses of wild resources by cultural groups) because of their nutritional value (Loureiro et al. 2015; White and Wilson 2015). In more recent years, seaweeds have been commercially harvested by food, biomedical, and cosmetic industries (Pereira 2015; White and Wilson 2015). As personal seaweed use has increased and as commercial harvesting is needed to 
meet global demands (Peteiro et al. 2014), methods for sustainable harvesting practices are continuing to develop (Marinho et al. 2015; Sharma et al. 2018).

The need to achieve sustainable harvesting practices is recognized world-wide (Springer et al. 2010; Vea and Ask 2011; Vásquez et al. 2012). Management concerns include the ecological effects of seaweed harvesting on the associated animal communities (Foster and Barilotti 1990), loss of fish habitat for spawning (Lorentsen et al. 2010; Kimura and Munehara 2011), recruitment of harvested seaweeds (Foster and Barilotti 1990; Steen et al. 2016), available biomass for sustained harvests (Ugarte and Sharp 2012), regrowth response following harvesting (Vea and Ask 2011; Steen et al. 2016), and harvesting methods (Foster and Barilotti 1990). For example, in Norway, the management of the kelp Laminaria hyperborea is based on a 5-year cycle of rotating harvest zones to assure regrowth to appropriate levels before a re-harvest is conducted (Vea and Ask 2011). In the Canadian Maritimes (Nova Scotia), sustained harvests of the rockweed Ascophyllum nodosum are based on manual harvesting methods (nonmechanized) to avoid overexploitation that would negatively impact recruitment and recovery of the resource (Ugarte and Sharp 2012). To conserve ecosystem function of A. nodosum in Maine, this rockweed must be harvested such that $40.5 \mathrm{~cm}$ of the plant remains above the holdfast (Arbuckle et al. 2014). In British Columbia, it has been recommended that harvests of the kelp Nereocystis luetkeana occur after spore release (Wheeler 1990). If harvested prior to spore release, these individuals would be removed from the reproductive pool and may reduce overall recruitment success of the population (Wheeler 1990; Springer et al. 2010). These few examples, of many, demonstrate how local knowledge of the ecological, reproductive, and growth characteristics of seaweeds is necessary to inform sustainable harvesting practices.

Impacts of harvest method on seaweed recovery should be considered when making regulatory decisions. Harvesting a portion of the thallus, instead of the whole thallus, results in preservation of ecological function and faster recovery rates. For example, in New Zealand, plots of Porphyra spp. that were experimentally harvested by leaving the holdfast attached recovered faster with greater biomass yields than those harvested of the entire thallus (Nelson and Conroy 1989). Similarly, in South Africa, selective cutting of Ecklonia maxima fronds, rather than entire thalli, resulted in survival of the individual kelps and faster regrowth rates (Levitt et al. 2002). The harvest method of removing only a portion of the individual has a similar effect to pruning, encouraging fuller regrowth of the crop (Monagail et al. 2017).

Seaweeds are capable of recovering following harvesting, but this ability is variable by species. Recovery of the kelp Saccharina latissima in Nova Scotia took 3 months to reach densities similar to that of non-harvested areas (Smith 1985). For the red seaweed, Gelidium pristoides, it took 3 to 4 months to regrow to comparable sizes and biomasses of non-harvested areas when harvested in early spring in South Africa (Carter and Anderson 1985). It took 9 months after harvest for the total recovery of biomass of the brown alga Sargassum cymosum in southern Brazil (Mafra Jr. and Cunha 2006). For the fast-growing kelp, Macrocystis pyrifera, harvest recovery to pre-harvest biomasses sometimes occurred within 3 to 4 weeks in British Columbia (Krumhansl et al. 2017). However, there is a negative relationship between seawater temperature and recovery rates following harvesting for the highly productive M. pyrifera (Krumhansl et al. 2017). As ocean temperatures are warming, particularly in the North Pacific (Vandersea et al. 2018), there is increasing concern for how climate change will impact harvest recovery (Krumhansl et al. 2017), thus threatening the sustainability of harvesting practices that do not adapt accordingly.

As is typical around the world, Southcentral Alaska has many harvested brown seaweeds including the genera Laminaria, Saccharina, Alaria, Fucus, and Nereocystis (Garza 2012). Personal use, subsistence, and commercial harvesting are all tightly managed by the Alaska Department of Fish and Game. In Southcentral Alaska, the Department of Fish and Game allows harvesting seaweed for subsistence and personal use only in designated areas. Regions designated as non-subsistence areas are currently closed to the taking of seaweeds that are attached and growing. Interest in harvesting seaweeds is growing but the impact of this activity on wild populations is poorly understood. In Southcentral Alaska, seaweed harvesting was allowed until an overharvest was perceived in the Seward area in 2006. This potential overharvest resulted in restrictions being approved by the Alaska Board of Fisheries. As such, a regulatory restriction went into effect to avoid the decline of seaweeds due to harvesting. Other regions of the world have achieved sustainability in open harvests through informed management (Ugarte and Sharp 2012), although knowledge of available biomass and regrowth of that biomass is key for sustainability.

Development of sustainable harvest strategies for wild seaweeds requires knowledge of the timing of reproduction and peak biomass availability for targeted species, as well as the rate of recovery by regrowth. To better understand how these factors may influence the harvestability of brown seaweeds in Southcentral Alaska, this study investigated reproductive timing, standing crop, and rebound rates following the removal of wild stocks of three commonly harvested species: Fucus distichus (rockweed), Saccharina latissima (sugar kelp), and Nereocystis luetkeana (bull kelp). Specifically, this study addressed the following questions: (1) Are Fucus, Saccharina, and Nereocystis reproductive during (or throughout) March to October, when they are most frequently targeted for harvesting?; (2) How much temporal and spatial variability is there in the standing crop of Fucus, Saccharina, and Nereocystis?; (3) Will the biomass of harvested Fucus, Saccharina, and 
Nereocystis rebound (i.e., regrowth and growth of recruits) within one summer?; and (4) At what size do Fucus, Saccharina, and Nereocystis become reproductive? Answers to these questions will help inform the development of sustainable harvest strategies for brown seaweeds in Southcentral Alaska.

\section{Methods}

\section{Study Area}

This study was conducted in Kachemak Bay, a large embayment in Lower Cook Inlet, Alaska from spring (March) until fall (October) 2018. Three rocky intertidal sites were chosen on the north side (Anchor Point, Bluff Point, and Bishop's Beach) and three on the south side (Jakolof Bay, Outside Beach, and Camel Rock) of the bay (Fig. 1). The north sites were in a non-subsistence area where harvesting live seaweed is currently prohibited. The south sites allow limited subsistence harvest. Four subtidal sites (Outside Beach, Hesketh Island, Jakolof Bay, and Herring Islands) were chosen on the south side of the bay as this is where Nereocystis is more common (Fig. 1).

\section{Environmental Classifications}

At each intertidal sampling site, substrate composition, wave exposure, and tidal elevation were characterized to facilitate evaluating correlations between environmental conditions and

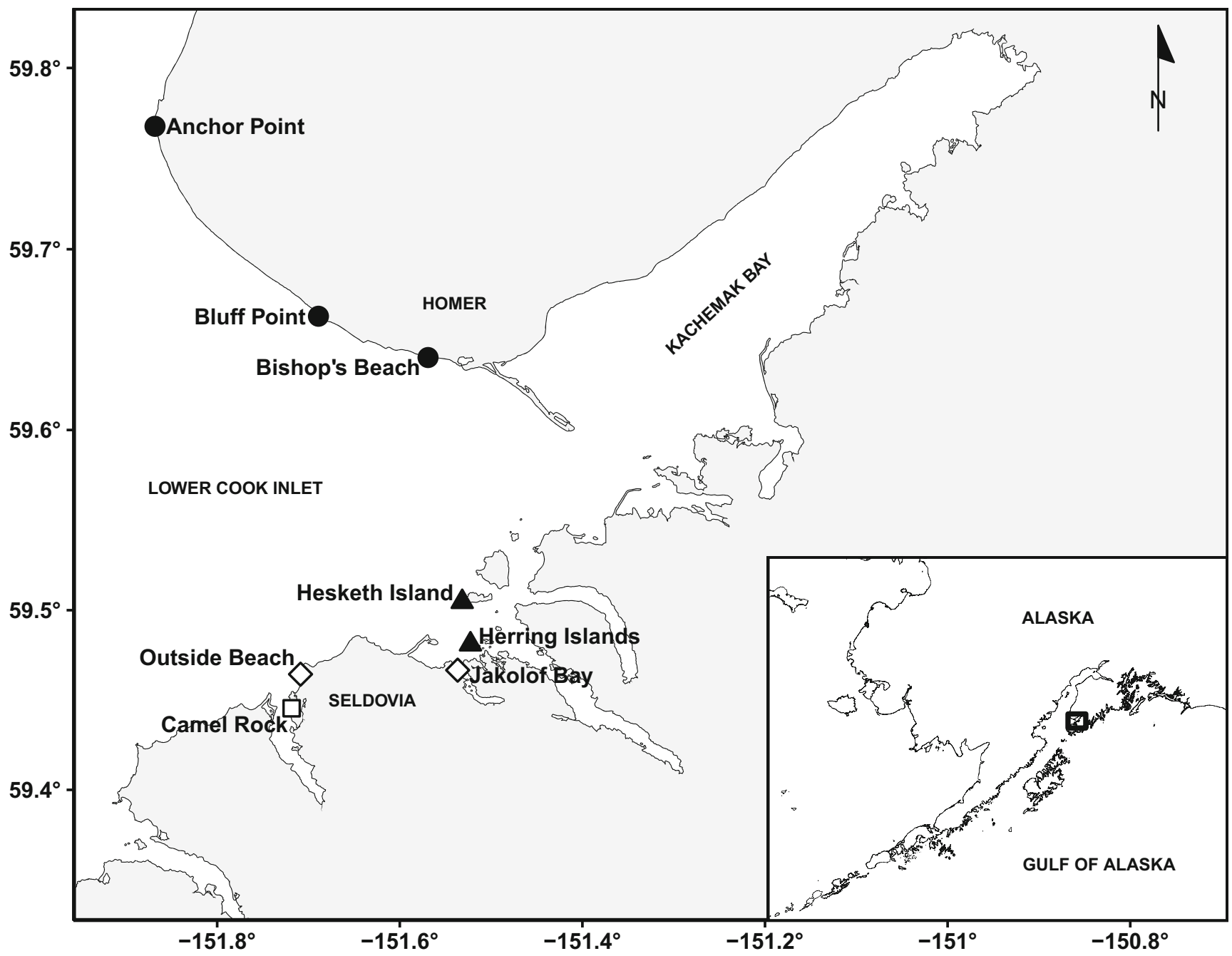

Fig. 1 Map of study sites located in Lower Cook Inlet (Northern Gulf of Alaska) at the mouth of Kachemak Bay. The three northern intertidal sites were Anchor Point, Bluff Point, and Bishop's Beach. The three southern intertidal sites were Jakolof Bay, Outside Beach, and Camel Rock. The four subtidal sites were at Outside Beach, Hesketh Island, Jakolof Bay, and Herring Islands. Sites were located either within (denoted by closed symbols) or outside (denoted by open symbols) non-subsistence boundaries. Circle = sites where Fucus and Saccharina were harvested. Triangle = sites where only Nereocystis was harvested. Diamond = sites where Fucus and Nereocystis were harvested. Square = sites where only Fucus was harvested 
seaweed biomass and growth. Substrate composition was classified at each intertidal site with ten $1-\mathrm{m}^{2}$ haphazardly placed quadrats within the rocky intertidal zone, from which percent cover of bedrock, boulder, cobble, gravel, and sand was visually estimated (Wentworth 1922). Wave exposure was determined by the "Biological Wave Exposure" data from NOAA's Alaska ShoreZone website (https://alaskafisheries. noaa.gov/mapping/sz_js/), under "Derived ShoreZone Attributes," where exposure ranks of exposed, protected, semi-exposed, or semi-protected are classified; classifications of wave exposure are estimated on the basis of observed indicator biota along the coastline. Tidal elevations were obtained from an unpublished light detection and ranging (LiDAR) dataset collected by NOAA and subsequently provided by the Kachemak Bay National Estuarine Research Reserve. Coordinates obtained from a GPS (Garmin GPSMAP 64s) were used to evaluate tidal height from the LiDAR dataset. Separate one-way ANOVAs for Fucus, Saccharina, and Nereocystis were used to compare biomass between sites categorized by different levels of wave exposure. For Fucus and Saccharina, correlations between site conditions (i.e., substrate type and tidal elevation) and standing crop were calculated with Spearman's rank correlation coefficients.

\section{Reproductive Timing}

To determine proportion of reproductive Fucus adults at each site over time, ten $0.25-\mathrm{m}^{2}$ quadrats were haphazardly placed in the "Fucus zone" each month, and individuals within the quadrats were counted and visually characterized as either reproductive or non-reproductive. Reproductive individuals were distinguished by having swollen receptacles bearing conceptacles (Evans et al. 1982; Pearson and Brawley 1996).

Reproductive tissues of Fucus were tested for reproductive viability by inducing gamete release in the lab (Ang 1991; Siméon and Hervé 2017). From each site, receptacles from five to ten haphazardly selected branches from different individuals of Fucus were rinsed with filtered seawater and macroscopic epiphytes were carefully removed. Receptacles were then wrapped in damp paper towels and placed in a dark $10^{\circ} \mathrm{C}$ cold room for $1 \mathrm{~h}$ to allow for a gentle desiccation (Redmond et al. 2014; Siméon and Hervé 2017). Following desiccation, each receptacle was placed in separate plastic cups filled with $100 \mathrm{~mL}$ of $10^{\circ} \mathrm{C}$ filtered seawater. Glass slides were placed at the bottom of each cup as a substrate for settling eggs. The cups were then maintained at $10^{\circ} \mathrm{C}$ with a photoperiod of $17 \mathrm{~h}$ of light ( $50 \mu \mathrm{mol}$ photons $\mathrm{m}^{-2} \mathrm{~s}^{-1}$ fluorescent lighting) and $7 \mathrm{~h}$ of darkness (Ang 1991; Siméon and Hervé 2017). This photoperiod was chosen to simulate the summer daylight hours of the high-latitude region from which the samples were collected. Cultivated Fucus were then observed for developing zygotes under a compound microscope (observed under both $\times 100$ to $\times 400$ total magnifications) after $72 \mathrm{~h}$. Individuals were scored as reproductively viable if settled zygotes began to cleave and show elongation in one hemisphere of the cell (Siméon and Hervé 2017). Eggs and zygotes were not quantified.

Due to limited access to Saccharina, only tide pool Saccharina were sampled from April to October at the three northern sites (i.e., Anchor Point, Bluff Point, and Bishop's Beach). These surveys consisted of noting the reproductive status of the first 20 individuals of Saccharina encountered at each site. Reproductive individuals were distinguished by blades bearing patches of sori. Saccharina was not tested for reproductive viability because reproductive individuals were not found until the end of the study period.

Nereocystis was initially sampled from subtidal sites at Outside Beach, Hesketh Island, and Jakolof Bay. After April, the Nereocystis bed at Jakolof Bay was too sparse to continue sampling, so a new site was chosen at the Herring Islands (Fig. 1). Surveys consisted of (1) swimming six $10 \times 2 \mathrm{~m}$ swaths through a Nereocystis bed on SCUBA and counting all adults (reached the water surface) and juveniles (did not reach the water surface), and (2) noting the reproductive status of adults at the surface (distinguished by blades bearing sori). Data collected from the underwater swath surveys were used to determine changes in adult and juvenile densities, while the surface surveys were used to determine changes in proportions of reproductive adults from early to late summer.

Sori from five to ten haphazardly selected blades of different Nereocystis individuals per site were tested for reproductive viability by inducing spore release in the lab each month (Deiman et al. 2012; Redmond et al. 2014; Traiger and Konar 2017). From each ripe sorus, standardized $2.5-\mathrm{cm}$ diameter discs were haphazardly removed from the patch and used for further analyses (Traiger and Konar 2017). The sori discs were rinsed with filtered seawater and gently scraped with a razorblade to remove any macroscopic epiphytes. Sori were then wrapped in damp paper towels and gently desiccated for $1 \mathrm{~h}$ in a dark $10^{\circ} \mathrm{C}$ cold room to stimulate a synchronous release of spores (Redmond et al. 2014). Each sorus was then placed in separate plastic cups filled with $100 \mathrm{~mL}$ of $10{ }^{\circ} \mathrm{C}$ filtered seawater and a glass slide and then placed under a photoperiod of $17 \mathrm{~h}$ of light $\left(50 \mu \mathrm{mol}\right.$ photons $\mathrm{m}^{-2} \mathrm{~s}^{-1}$ fluorescent lighting) and $7 \mathrm{~h}$ of darkness (Deiman et al. 2012; Redmond et al. 2014). Again, this photoperiod was chosen to simulate the summer daylight hours from this high-latitude region. Microscope slides were observed under a compound microscope ( $\times 400$ total magnification) for settled and germinating spores after $48 \mathrm{~h}$. Viable spores were characterized by the presence of a germ tube. Spores were not quantified.

For all three target species, timing of when individuals were reproductive and density differences were assessed. Separate ANOVAs (by species and site) were used to determine variability in densities and proportions of reproductive individuals over time from early to late summer. When ANOVA tests suggested significance, Tukey honest 
significant difference (HSD) post hoc tests were carried out to confirm pairwise differences.

\section{Standing Crop}

In this study, standing crop is defined as total wet weight of individuals within $1-\mathrm{m}^{2}$ sample plots (i.e., $\mathrm{kg} / \mathrm{m}^{2}$ ). To determine variability in standing crop from early to late summer, Fucus and Nereocystis were cleared in marked quadrats every other month from March to September (i.e., March, May, July, and September). Similarly, Saccharina was harvested every other month from April to October (i.e., April, June, August, and October) in marked quadrats. Fucus was harvested at all six intertidal sites, whereas Saccharina was only harvested at the three northern sites as these were the only sites where this species was found. Nereocystis was harvested only at the four southern subtidal sites because this species was uncommon on the northern side of the bay (Traiger and Konar 2018).

For Fucus and Saccharina, at each site, six haphazardly selected $1-\mathrm{m}^{2}$ plots (containing a minimum of at least five individuals) were marked and cleared of all adult Fucus or Saccharina, depending on type of clearing being performed. Fucus individuals larger than $2 \mathrm{~cm}$ were harvested just above the holdfast, which means the apical meristems were removed as they are situated at the distal end of their branches (Moss 1967). Saccharina were harvested approximately $5 \mathrm{~cm}$ above the stipe-blade junction so that the holdfast and meristem at the proximal end of the blade remained. These reflected common methods used by wild seaweed harvesters (Marine Scotland Directorate 2016).

For Nereocystis, twelve $16-\mathrm{m}^{2}$ plots were marked at the subtidal sites. Nereocystis plots were larger than the intertidal plots because this species is not as dense as Fucus or Saccharina. In six of the plots, Nereocystis individuals were collected at the base of the stipe just above the holdfast. In the other six plots, only the Nereocystis blades were harvested by cutting them approximately $5 \mathrm{~cm}$ above the pneumatocystblade junction so that the meristems at the proximal ends of the blades remained (Nicholson 1970). Both harvesting styles were applied as they are two common methods for harvesting Nereocystis (Springer et al. 2010). For the blade clearings, individuals whose holdfasts were attached within the plot were pulled down to the bottom by a diver, the blades were removed and bagged, and then the pneumatocyst was released back to the surface. Most plots that were cleared had an initial abundance of at least five individuals, but due to overall lower densities in early summer, some plots had an initial abundance of only two individuals.

For all species, all harvested individuals or blades were bagged by the plot from which they were collected and brought to the NOAA/UAF Kasitsna Bay Laboratory in coolers or buckets filled with seawater. At the lab, harvested materials from the clearings were weighed for overall biomass, individuals of
Fucus and stipes of Nereocystis were counted and measured for length, and all individuals were checked for reproductive status (using methods described below). A separate one-way ANOVA and a Tukey HSD post hoc test for each species were used to compare biomass over time and across sites to examine temporal and spatial variability of standing crop.

\section{Harvest Rebound}

To determine biomass regrowth of Fucus and Nereocystis, half of the plots initially harvested in March, May, and July were re-cleared 2 months later (i.e., initial March clearings were re-cleared in May, initial May clearings were re-cleared in July, and initial July clearings were re-cleared in September). The other half of the plots initially harvested in March and May were re-cleared in September to determine rebound rates after 6 and 4 months, respectively. For Saccharina, half of the plots were re-cleared 2 months after the April, June, and August clearings (i.e., initial April clearings were re-cleared in June, etc.). Again, the other half of the plots initially harvested in April and June were re-cleared at the end of the sampling period in October to determine regrowth after 6 and 4 months, respectively. Re-cleared plots were cleared by the same method used in the initial clearings to determine regrowth throughout the sampling period and for Nereocystis, by the clearing method (e.g., if only Nereocystis blades were initially cleared from a plot, then re-clearings of that plot would be of only the blades). Harvested seaweeds from the re-clearings were processed similarly as the harvested seaweeds from the initial clearings. Using a one-way ANOVA and a Tukey HSD post hoc test by species, biomass not previously harvested was compared to rebound biomass after 2, 4, and 6 months to examine how quickly the biomass of harvested Fucus, Saccharina, and Nereocystis rebounded within one summer.

\section{Reproductive Size}

From the biomass sampling, length measurements from individuals were used to determine the size at which Fucus and Nereocystis become reproductive. Due to a lack of reproductive Saccharina, minimum reproductive size of Saccharina could not be determined. From the Fucus clearings, plots were subsampled ( $n=50$ individuals per plot) and individuals were measured (to nearest $\mathrm{mm}$ ) for length from the holdfast to the tip of the longest branch and reproductive status determined. All individuals from the Nereocystis clearings were measured (to nearest $\mathrm{cm}$ ) for stipe length from the holdfast to the center of the pneumatocyst. An ANOVA by species was applied to test if the size at which individuals become reproductive was spatially variable. The replicates used for these analyses were the smallest reproductive individuals from each plot at each site. 
Table 1 Environmental classifications of substrate type (mean percentage \pm standard deviation; $n=10$ plots per site), wave exposure, and tidal elevation for the six intertidal sites

\begin{tabular}{lccccccc}
\hline & Bedrock (\%) & Boulder (\%) & Cobble (\%) & Gravel (\%) & Sand (\%) & Wave exposure & Tidal elevation (m) \\
\hline Anchor Point & $0.0 \pm 0.0$ & $79.5 \pm 14.0$ & $8.75 \pm 7.0$ & $1.25 \pm 2.0$ & $10.5 \pm 13.0$ & SE & -0.55 \\
Bluff Point & $0.0 \pm 0.0$ & $85.0 \pm 16.0$ & $1.0 \pm 3.0$ & $6.0 \pm 14.0$ & $8.0 \pm 8.0$ & SE & 0.58 \\
Bishop's Beach & $27.0 \pm 44.0$ & $58.0 \pm 40.0$ & $3.0 \pm 4.0$ & $11.5 \pm 6.0$ & $0.5 \pm 2.0$ & SP & SP \\
Jakolof Bay & $100.0 \pm 0.0$ & $0.0 \pm 0.0$ & $0.0 \pm 0.0$ & $0.0 \pm 0.0$ & $0.0 \pm 0.0$ & SP \\
Outside Beach & $75.6 \pm 41.0$ & $20.2 \pm 39.0$ & $0.3 \pm 1.0$ & $3.9 \pm 7.0$ & $0.0 \pm 0.0$ & SE & ND \\
Camel Rock & $50.1 \pm 40.0$ & $42.0 \pm 36.0$ & $5.7 \pm 5.0$ & $2.2 \pm 4.0$ & $0.0 \pm 0.0$ & SE & ND \\
\hline
\end{tabular}

$S E=$ semi-exposed; $S P=$ semi-protected; $N D=$ no data

\section{Results}

\section{Environmental Classifications}

Substrate type varied across rocky intertidal sites (Table 1). Boulder was the predominant substrate type at the three northern intertidal sites, consistently comprising more than $50 \%$ of the substrate. Sand was also consistently present at the northern sites, whereas the three southern sites were characterized more by bedrock and no sand, with Jakolof Bay having $100 \%$ bedrock. The southernmost site on the north side of the bay (Bishop's Beach) resembled the southern sites, with higher percent cover of bedrock and a lower percent cover of boulder and sand. Substrate type was not measured for the subtidal sites, but all chosen Nereocystis beds were situated on bedrock and large, scattered boulders.

The innermost intertidal sites along the north and south sides of the bay (Bishop's Beach and Jakolof Bay, respectively) were both semi-protected. The other four intertidal sites (Anchor Point, Bluff Point, Outside Beach, and Camel Rock) were all semi-exposed. The two outermost subtidal sites (Outside Beach and Hesketh Island) were semi-exposed, while the two innermost sites (Jakolof Bay and Herring Islands) were semi-protected (Alaska ShoreZone).

Tidal elevations derived from the LiDAR dataset were only available for the three northern intertidal sites (Table 1). Consequently, the three southern sites were not included in tidal elevation analyses. Plots within the rocky intertidal site at Anchor Point had a much lower tidal distribution $(-0.55 \mathrm{~m})$ compared to those at Bluff Point $(0.58 \mathrm{~m})$ and Bishop's Beach $(1.16 \mathrm{~m})$.

\section{Reproductive Timing}

In March, reproductive Fucus was present at only two of the six sites (Jakolof Bay and Camel Rock). Beginning in April, there was a general increase in proportions of reproductive Fucus before a synchronous decline across sites in August and September. Although Fucus was present at all sites during March to October, individuals were mostly reproductive in May, June, and July (Fig. 2a). Spatially, the proportions of reproductive Fucus across sites were significantly variable (ANOVA, $F_{5,414}=9.89, p=0.001$ ) throughout the summer. Fucus densities were also significantly variable across sites (ANOVA, $F_{5,414}=49.58, p=0.001$ ). At Anchor Point, overall Fucus density was significantly lower over time relative to Bluff Point, Bishop's Beach, and Outside Beach (Supplementary Table 1). The reproductive proportions of those individuals at Anchor Point were also significantly lower relative to Bishop's Beach, Jakolof Bay, Outside Beach, and Camel Rock (Fig. 2a; Supplementary Table 1). Densities observed at Bluff Point were significantly higher than Anchor Point, Bishop's Beach, Jakolof Bay, Outside Beach, and Camel Rock (Fig. 2a; Supplementary Table 1). Densities of Fucus at Bishop's Beach were the next highest and were significantly higher than Anchor Point, Jakolof Bay, Outside Beach, and Camel Rock (Supplementary Table 1). These two higher-density sites (Bluff Point and Bishop's Beach) had proportions of reproductive individuals comparable to the other three sites (Jakolof Bay, Outside Beach, and Camel Rock) with mid-range densities (Supplementary Table 1). The greatest proportion of reproductive Fucus was observed in April (66.4 $\pm 23 \%, n=10$ plots) at Camel Rock (Fig. 2a). There was no significant difference in proportions of reproductive Fucus between semi-exposed and semi-protected sites (ANOVA, $F_{1,418}=2.45, p=0.118$ ).

Reproductive Saccharina was not found until October, during the last sampling event. At this time, the proportion of reproductive Saccharina was 85, 5, and 0\% at Anchor Point, Bluff Point, and Bishop's Beach, respectively. Overall densities of Saccharina were not assessed.

Due to the presence of reproductive overwintered adults in spring, Nereocystis was found to be reproductive throughout the entire study period (Table 2). Although the overall proportions of reproductive individuals increased from March to September, the proportions of reproductive adults showed no significant differences over time (ANOVA, $F_{6,14}=0.84, p=$ 0.557 ) or among sites (ANOVA, $F_{3,17}=1.12, p=0.369$; Table 2). While total Nereocystis densities generally increased from early to late summer, sites were most dense in May, June, and July, as juveniles were increasing in number (Fig. 2b). 


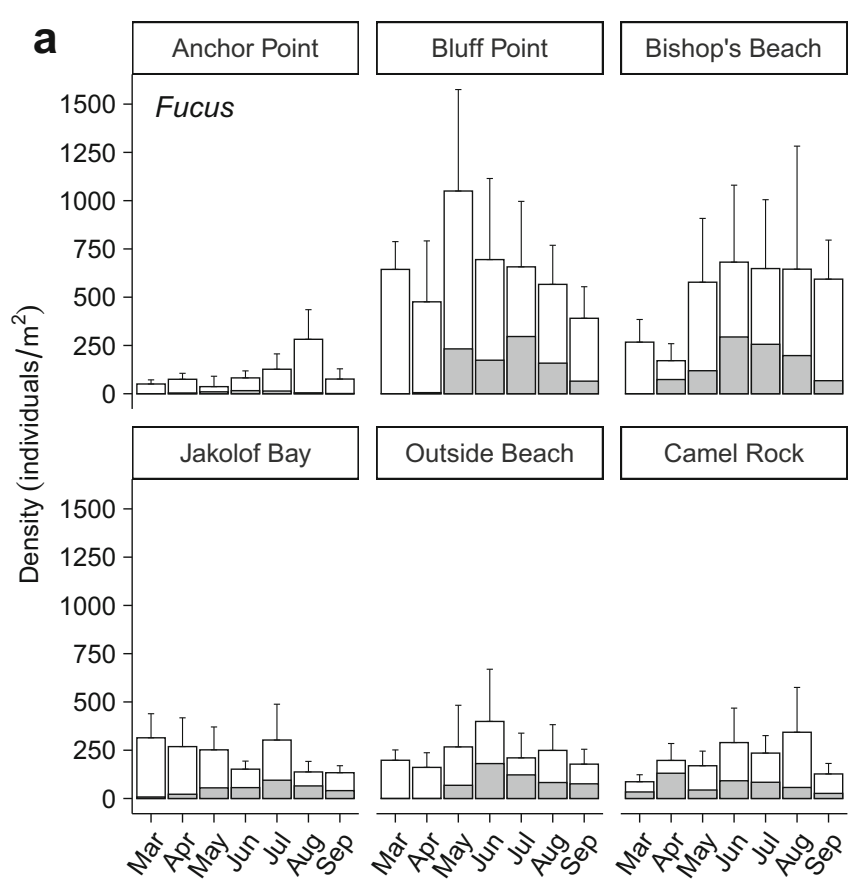

Fig. 2 a Average densities and standard deviations of Fucus and proportions that are reproductive (gray shaded area of bars) at each site over time. b Average densities and standard deviations of Nereocystis at

Hesketh Island had overall significantly higher densities of Nereocystis throughout the summer $\left(1.49 \pm 2.2 \mathrm{ind} . / \mathrm{m}^{2}, n=\right.$ 42 plots; ANOVA, $F_{3,122}=5.44, p=0.002$; Fig. $2 \mathrm{~b}$ ) and had the most recruits relative to the other sites, with 215 juveniles counted in one of the May $10 \mathrm{~m} \times 2 \mathrm{~m}$ swaths. There was no significant difference in proportions of reproductive Nereocystis between semi-exposed and semi-protected sites (ANOVA, $F_{1,19}=2.44, p=0.134$ ).

\section{Standing Crop and Harvest Rebound}

While standing crop was spatially variable, there was a general increase from early to late summer for all three species at most sites. Fucus biomass (all sites combined) was significantly different over time (ANOVA, $F_{3,103}=9.24, p=$ 0.00002), with July having higher average standing crop,

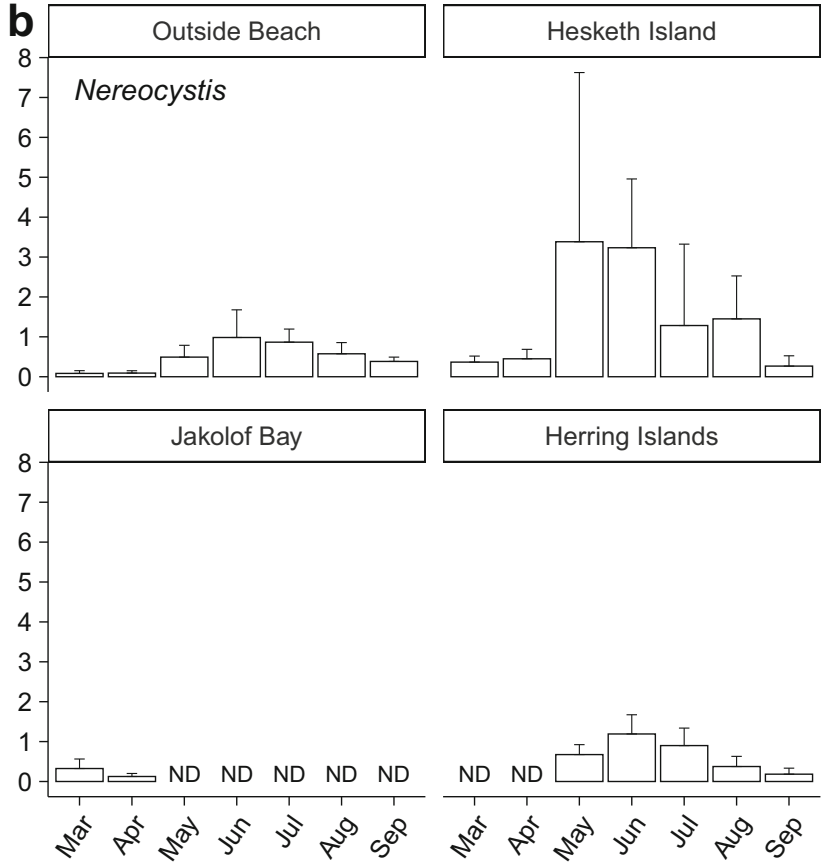

each site over time. Reproductive proportions of Nereocystis are not shown here because they were not assessed from these density collections. $\mathrm{ND}=$ no data

compared to the overall lowest average in March (Fig. 3a). Standing crop of Fucus was also significantly different among sites (ANOVA, $F_{5,101}=7.39, p=0.001$ ). At Anchor Point, standing crop of Fucus (all months combined) was significantly lower than standing crops at Bluff Point, Bishop's Beach, Jakolof Bay, and Camel Rock (Supplementary Table 2). When analyzed by month, Fucus at Camel Rock had the most temporal variability in standing crop from early to late summer, with significantly higher biomass in July compared to the other months (ANOVA, $F_{3,14}=28.37, p=0.001$; Fig. 3a). Standing crop of Fucus at Jakolof Bay did not differ significantly over time (ANOVA, $F_{3,14}=2.77, p=$ 0.08 ), nor did it differ significantly over time at Outside Beach (ANOVA, $F_{3,14}=3.01, p=0.07$; Fig. 3a). Standing crop at the other sites (Anchor Point, Bluff Point, and Bishop's Beach) had similar temporal trends to one
Table 2 Reproductive proportions of Nereocystis ( $n=$ number of individuals surveyed). After April, there was a relocation of study site from Jakolof Bay to the Herring Islands

\begin{tabular}{lllll}
\hline & Outside Beach & Hesketh Island & Jakolof Bay & Herring Islands \\
\hline March & $20.0 \%(n=10)$ & $95.5 \%(n=44)$ & $92.3 \%(n=39)$ & ND \\
April & $70.0 \%(n=20)$ & $100 \%(n=20)$ & $70.0 \%(n=20)$ & ND \\
May & $76.2 \%(n=21)$ & $94.1 \%(n=17)$ & ND & $95.5 \%(n=22)$ \\
June & $75.0 \%(n=4)$ & $100 \%(n=20)$ & ND & $95.0 \%(n=20)$ \\
July & $50.0 \%(n=14)$ & $30.0 \%(n=20)$ & ND & $100 \%(n=7)$ \\
August & $65.0 \%(n=20)$ & $25.0 \%(n=20)$ & ND & $90.0 \%(n=20)$ \\
September & $100 \%(n=20)$ & $95.0 \%(n=20)$ & ND & $81.3 \%(n=16)$ \\
\hline
\end{tabular}

$N D=$ no data 


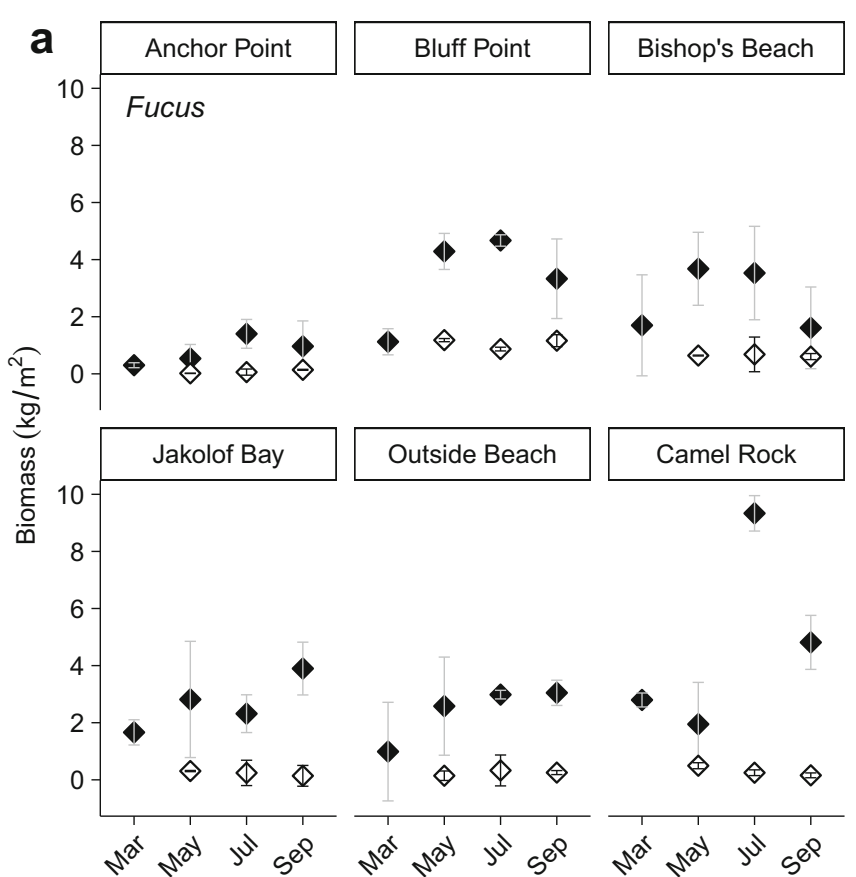

Fig. 3 Average standing crop, average rebounded biomass, and standard deviations of Fucus. a Standing crop of Fucus over time and harvest rebound after 2 months. Black diamonds denote the standing crop available if not previously harvested. White diamonds denote the biomass available for harvest if previously harvested 2 months earlier,

another. At Anchor Point, standing crop was significantly different over time (ANOVA, $F_{3,14}=19.25, p=0.001$ ), with more biomass in July and September than in March (Fig. 3a). At Bluff Point, standing crop was also significantly different over time (ANOVA, $F_{3}, 13=7.87, p=$ 0.003 ), with more biomass in May and July than in March (Fig. 3a). Similarly, at Bishop's Beach, standing crop was significantly different over time (ANOVA, $F_{3}$, $14=4.52, p=0.02$ ), with more biomass in May than in March (Fig. 3a). Overall, standing crop was consistently significantly lower in March for the three sites on the north side of the bay.

Fucus biomass that rebounded 2 months after harvesting generally remained low throughout the growing season with significant spatial differences in recovery (ANOVA, $F_{5,48}=$ 21.17, $p=0.001$; Fig. 3a). Rebounded biomass after 2 months at Bluff Point yielded significantly more biomass compared to that of Anchor Point, Bishop's Beach, Jakolof Bay, Outside Beach, and Camel Rock (Supplementary Table 2). Harvest rebound at Bishop's Beach after 2 months also had significantly more biomass than Anchor Point, Jakolof Bay, Outside Beach, and Camel Rock (Supplementary Table 2). The sites that had greater amounts of standing crop following harvesting 2 months prior (Fig. 3a) were also the sites with higher densities (Bluff Point and Bishop's Beach; Fig. 2a; Supplementary Table 1). In September, biomass that rebounded after 4 months of growth (i.e., May to

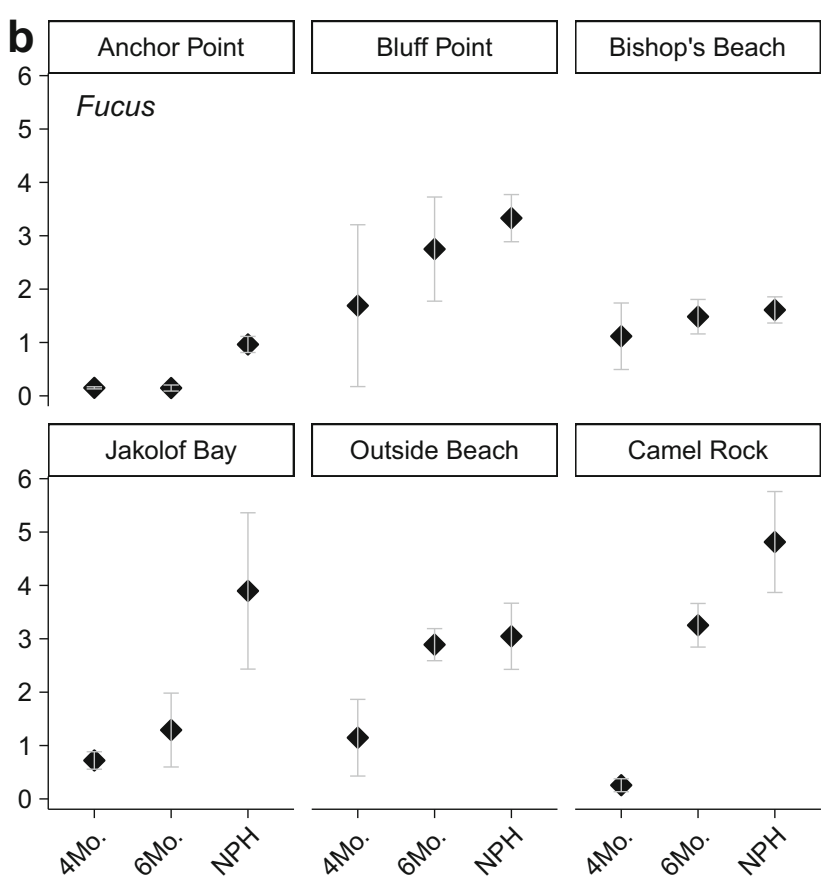

showing the amount of regrowth after 2 months. b Biomass available for harvest in September if previously harvested 4 and 6 months earlier, and biomass harvested in September from not previously harvested (NPH) plots. $\mathrm{NPH}=$ not previously harvested before September

September) remained significantly lower than the not previously harvested (NPH) September biomass yields at Anchor Point, Jakolof Bay, Outside Beach, and Camel Rock (Fig. 3b; Supplementary Table 3). Rebounded biomass after 4 months of growth at Bluff Point and Bishop's Beach yielded biomasses similar to the NPH September biomass yields (Fig. 3b; Supplementary Table 3), whereas given 6 months of regrowth (i.e., March to September), Bluff Point, Bishop's Beach, Outside Beach, and Camel Rock rebounded to biomasses that were not significantly different from the NPH September biomass yields (Supplementary Table 3). On the other hand, Anchor Point and Jakolof Bay rebounded to biomasses that remained significantly lower than the NPH September biomass yields (Fig. 3b; Supplementary Table 3).

Saccharina standing crop increased from early to late summer at only Anchor Point, while standing crop at Bluff Point and Bishop's Beach only increased early in the summer before decreasing by August (Fig. 4a). Saccharina standing crop (all months combined) was weakly significantly different among sites (ANOVA, $F_{2,51}=3.45, p=0.04$; Supplementary Table 2). In April, mean standing crop at Anchor Point $\left(0.58 \pm 0.3 \mathrm{~kg} / \mathrm{m}^{2}, n=6\right.$ plots $)$ was similar to that of Bluff Point $\left(0.60 \pm 0.6 \mathrm{~kg} / \mathrm{m}^{2}, n=6\right.$ plots; Fig. $\left.4 \mathrm{a}\right)$. Unlike Bluff Point and Bishop's Beach, however, Saccharina standing crop at Anchor Point continued to increase from April to August, reaching the maximum overall mean biomass in August (1.24 $\pm 0.9 \mathrm{~kg} / \mathrm{m}^{2}, n=3$ plots; Fig. 4a). At Bluff Point and Bishop's 


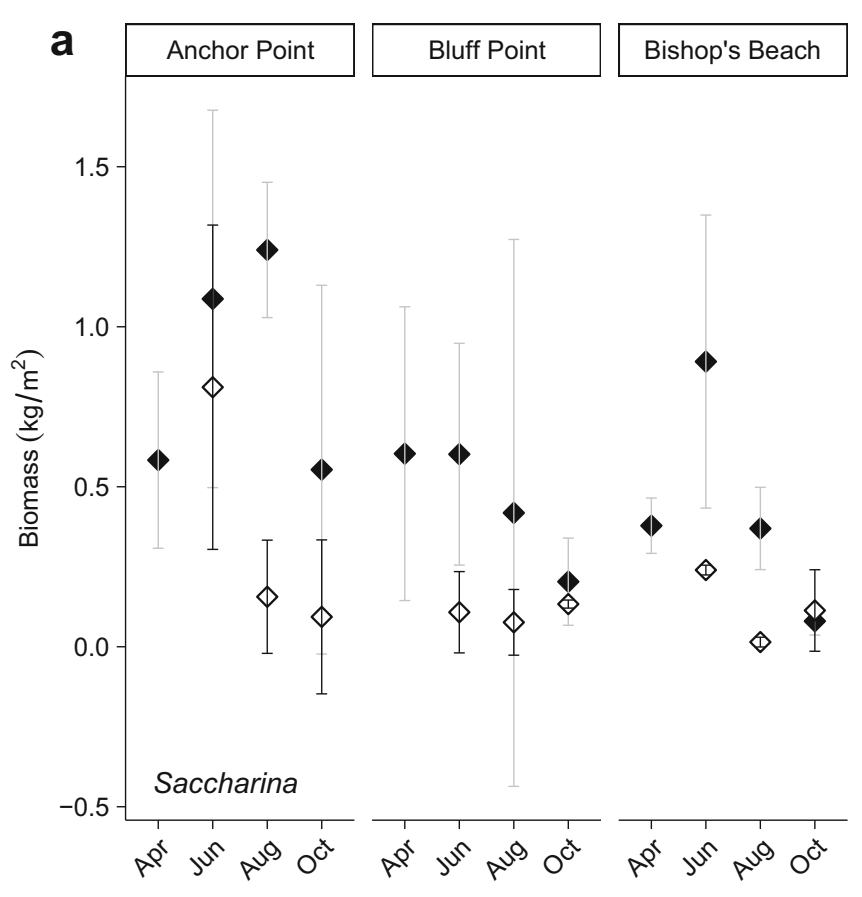

Fig. 4 Average standing crop, average rebounded biomass, and standard deviations of Saccharina. a Standing crop of Saccharina over time and harvest rebound after 2 months. Black diamonds denote the standing crop available if not previously harvested. White diamonds denote the biomass available for harvest if previously harvested 2 months earlier, showing the

Beach, standing crop increased from April to June, but started to decrease after June or July (Fig. 4a). All three sites had decreasing standing crop from August to October (Fig. 4a).

Saccharina biomass that rebounded 2 months after harvesting also remained low throughout the growing season, showing no significant difference among sites (ANOVA, $F_{2,24}=2.29$, $p=0.123$; Fig. 4a; Supplementary Table 2). Two exceptions of high regrowth after 2 months occurred: one at Anchor Point from April to June and one at Bishop's Beach from August to October (Fig. 4a). In October, biomass that rebounded after 4 months of growth (i.e., June to October) was similar to the NPH October yields at Anchor Point, Bluff Point, and Bishop's Beach (Fig. 4b; Supplementary Table 3). Similarly, biomass that rebounded after 6 months of growth (i.e., April to October) was similar to the NPH October yields at Anchor Point, Bluff Point, and Bishop's Beach (Supplementary Table 3).

Both harvesting styles of Nereocystis (i.e., whole thallus or just the blades) had no clear pattern of standing crop from early to late summer, with weak significant differences among sites for whole Nereocystis clearings (ANOVA, $F_{3,50}=2.82$, $p=0.05)$ and no significant differences among sites for Nereocystis blade clearings (ANOVA, $F_{3,50}=2.06, p=0.12$; Supplementary Table 2). However, there was an increasing trend in biomass over time at Outside Beach (Fig. 5 a and c). Mean standing crop of whole Nereocystis individuals (i.e., from whole thallus clearings) at Outside Beach increased

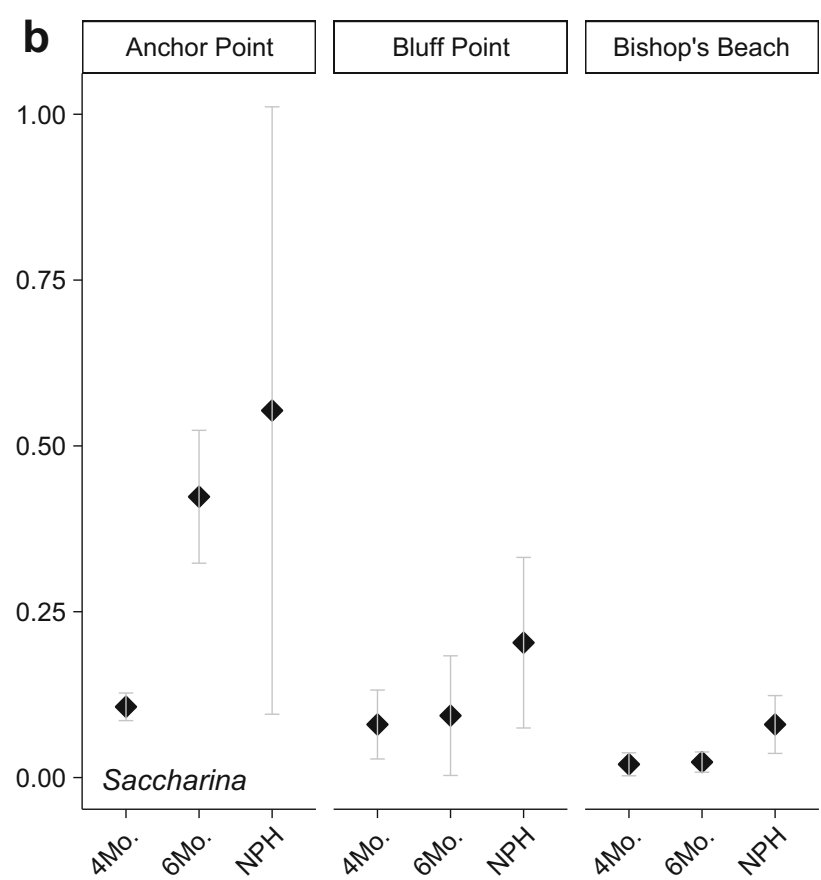

amount of regrowth after 2 months. b Biomass available for harvest in October if previously harvested 4 and 6 months earlier, and biomass harvested in October from not previously harvested (NPH) plots. NPH $=$ not previously harvested before October

from May $\left(0.10 \pm 0.1 \mathrm{~kg} / \mathrm{m}^{2}, n=6\right.$ plots $)$ to the greatest overall biomass in September $\left(2.63 \pm 1.0 \mathrm{~kg} / \mathrm{m}^{2}, n=3\right.$ plots; Fig. 5a). Standing crop at Outside Beach was significantly higher in September (ANOVA, $F_{3,14}=12.73, p=0.0003$ ). The other sites had no temporal trends (Fig. 5a).

Nereocystis biomass from whole thallus clearings that rebounded 2 months after harvesting was not significantly different among sites (ANOVA, $F_{3,23}=0.87, p=0.47$; Supplementary Table 2), but was significantly lower than standing crop yields throughout the summer at all sites (Fig. 5a; Supplementary Table 3). In September, after 4 months of regrowth (i.e., May to September), Nereocystis biomass was still significantly lower than the NPH September harvests at Outside Beach and Hesketh Island, but not at the Herring Islands (Fig. 5b; Supplementary Table 3). After 6 months of regrowth (i.e., March to September), re-cleared plots in September at Outside Beach yielded biomasses similar to the NPH September harvests (Supplementary Table 3); Herring Islands data were not taken since the sampling location was relocated to the Herrings Islands in May, and revisited plots at Hesketh Island and Jakolof Bay were absent of Nereocystis individuals (Fig. 5b).

The mean standing crop of Nereocystis blades (i.e., blade clearings) was not significantly different among sites (ANOVA, $F_{3}, 50=2.06, p=0.12$; Supplementary Table 2). Outside Beach, again, increased in biomass from early to late 


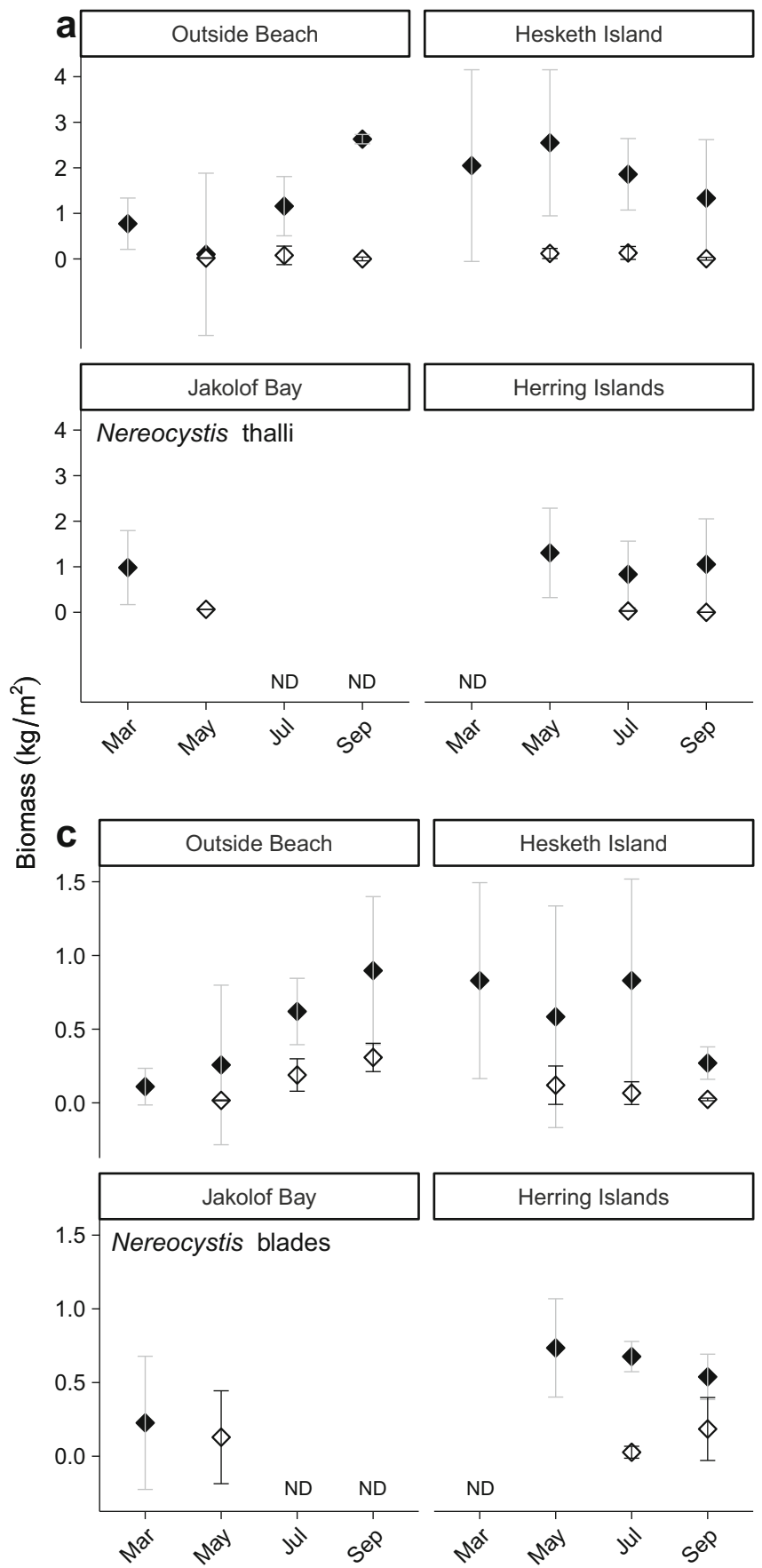

Fig. 5 Average standing crop, average rebounded biomass, and standard deviations of Nereocystis. Standing crop over time and harvest rebound after 2 months for a whole Nereocystis thalli and $\mathbf{c}$ just Nereocystis blades. Black diamonds denote the standing crop available if not previously harvested. White diamonds denote the biomass available for harvest if previously harvested 2 months earlier, showing the amount of regrowth

summer, but had no significant differences over time (ANOVA, $\left.F_{3,14}=2.80, p=0.08\right)$. The overall greatest biomass of Nereocystis blades was measured in September $(0.90 \pm$ $0.3 \mathrm{~kg} / \mathrm{m}^{2}, n=3$ plots) at Outside Beach (Fig. $5 \mathrm{c}$ ). The greatest
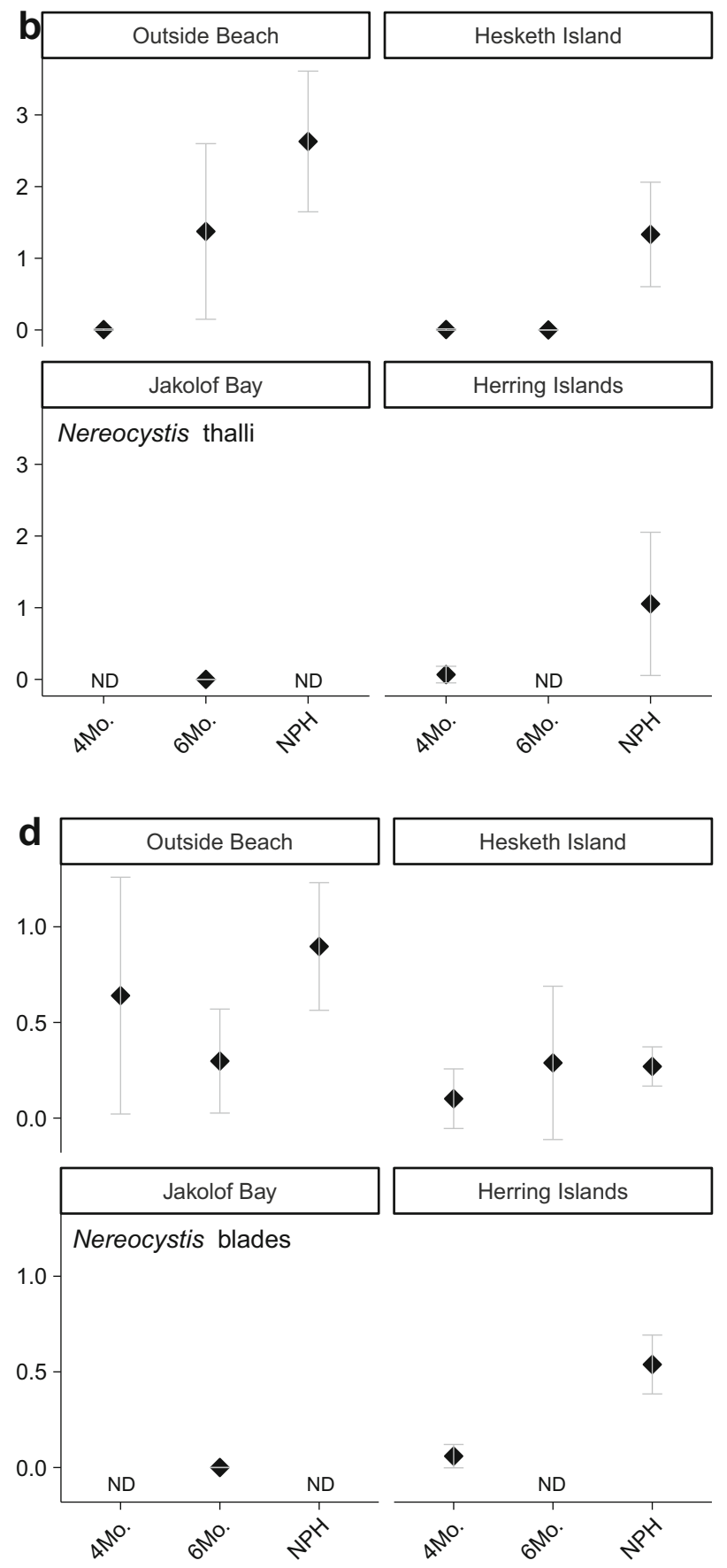

after 2 months. Biomass available for harvest in September if previously harvested 4 and 6 months earlier, and biomass harvested in September from not previously harvested (NPH) plots for $\mathbf{b}$ whole Nereocystis thalli and $\mathbf{d}$ just Nereocystis blades. NPH $=$ not previously harvested before September. ND $=$ no data

biomass measured at Hesketh Island was similar in both March $\left(0.83 \pm 0.5 \mathrm{~kg} / \mathrm{m}^{2}, n=6\right.$ plots $)$ and July $\left(0.83 \pm 0.1 \mathrm{~kg} / \mathrm{m}^{2}, n=3\right.$ plots), while the greatest biomass measured at the Herring Islands was in May $\left(0.73 \pm 0.8 \mathrm{~kg} / \mathrm{m}^{2}, n=6\right.$ plots; Fig. $\left.5 \mathrm{c}\right)$. 
Table 3 (a) Spearman's rank correlation coefficients between biomass and environmental variables. (b) ANOVA comparisons of mean standing crop and mean harvest rebound between semi-exposed and semi-protected sites

\begin{tabular}{llccccc}
\hline (a) & Bedrock & Boulder & Cobble & Gravel & Sand & Tidal elevation \\
Fucus biomass & $0.21^{*}$ & -0.13 & $-0.26^{* *}$ & 0.097 & $-0.35^{* * *}$ & $0.62^{* * *}$ \\
Saccharina biomass & -0.14 & -0.028 & $0.29^{*}$ & -0.028 & 0.26 & -0.26 \\
(b) & SE vs. SP & & & \\
& Standing crop & & Harvest rebound \\
Fucus & $F_{1,106}=0.06, p=0.8$ & & $F_{1,88}=0.32, p=0.576$ \\
Saccharina & $F_{1,52}=1.70, p=0.198$ & & $F_{1,43}=2.81, p=0.1$ & \\
Nereocystis thalli & $F_{1,52}=1.15, p=0.288$ & & $F_{1,41}=1.19, p=0.282$ & \\
Nereocystis blades & $F_{1,52}=0.003, p=0.956$ & & $F_{1,43}=2.48, p=0.122$ & \\
\hline
\end{tabular}

$S E=$ semi-exposed; $S P=$ semi-protected

${ }^{*} p<0.05 ; * * p<0.01 ; * * * p<0.001$
Nereocystis blade biomass that rebounded after 2 months was not significantly different among sites (ANOVA, $F_{3,23}=$ $0.65, p=0.59$; Supplementary Table 2). However, blade biomass that rebounded after 2 months was significantly lower than blade standing crop yields throughout the summer at Hesketh Island and the Herring Islands, but not at Outside Beach and Jakolof Bay (Fig. 5c; Supplementary Table 3). In September, biomass of Nereocystis blades that rebounded after 4 months of growth (i.e., May to September) at the Herring Islands remained significantly lower than the NPH September biomass yields (Fig. 5d; Supplementary Table 3). Given 4 months of regrowth (i.e., May to September), rebounded blade biomass yields at Outside Beach and Hesketh Island were similar to the NPH September biomass yields (Fig. 5d; Supplementary Table 3). Similarly, given 6 months of regrowth (i.e., March to September), rebounded biomass yields were similar to NPH September biomass yields at Outside Beach and Hesketh Island (Fig. 5d; Supplementary Table 3). Since sampling location was relocated from Jakolof Bay to the Herring Islands in May, harvest rebound after 4 months could not be measured at Jakolof Bay. After 6 months, revisited plots at Jakolof Bay were completely absent of Nereocystis, so blade regrowth was zero (Fig. 5d).

There were no significant differences in standing crop of Fucus, Saccharina, Nereocystis thalli, and Nereocystis blades between semi-exposed and semi-protected sites (Table 3). Similarly, there were no significant differences in overall rebounded biomass for Fucus, Saccharina, Nereocystis thalli, and Nereocystis blades between semi-exposed and semiprotected sites (Table 3 ). There was a positive correlation between Fucus standing crop and tidal elevation (Spearman, $R_{\mathrm{S}}=0.62, p=6.5 \mathrm{e}-07$ ), where Fucus biomass increased at higher tidal elevations (Table 3). An opposite trend occurred for Saccharina, where higher biomass was recorded at the site with the lowest tidal height (Table 3). Standing crop for Fucus and Saccharina also followed opposite trends when evaluated against substrate type (Table 3). For example, there was more Fucus (less Saccharina) biomass when percent bedrock was greater, but less Fucus (more Saccharina) when percent sand was greater (Table 3 ).

\section{Reproductive Size}

The size at which Fucus became reproductive overall averaged $11.9 \pm 5.9 \mathrm{~cm}(n=76$ individuals; Fig. 6a). The smallest reproductive size was similar across sites except for Anchor Point, where the smallest reproductive individuals were significantly larger ( $24.1 \pm 8.2 \mathrm{~cm}, n=9$ individuals) relative to the other sites $\left(10.3 \pm 2.8 \mathrm{~cm}, n=67\right.$ individuals; ANOVA, $F_{5}$, $70=26.31, p=0.001 ;$ Fig. $6 \mathrm{a})$. Though the smallest reproductive Fucus individuals were consistently larger at Anchor Point, the overall largest reproductive Fucus was from Camel Rock at $52.2 \mathrm{~cm}$. The largest reproductive individuals at Anchor Point were greater than $40 \mathrm{~cm}$, while the largest reproductive individuals at Bluff Point, Bishop's Beach, Jakolof Bay, and Outside Beach were between 20 and $30 \mathrm{~cm}$.

For Nereocystis, the stipe lengths of the smallest reproductive individuals were significantly smaller (ANOVA, $F_{3,36}=$ $8.40, p=0.0002)$ in September $(355.8 \pm 146.8 \mathrm{~cm}, n=9$ individuals) than March through July $(671.1 \pm 191.6 \mathrm{~cm}, n=31$ individuals). Overwintered Nereocystis (individuals already reaching the surface in March) accounted for all of the individuals measured in spring, which were on average $810.3 \pm$ $198.5 \mathrm{~cm}(n=49$ individuals) in stipe length and reproductive. The smallest reproductive overwintered individuals were significantly different across sites in March (ANOVA, $F_{2,11}=$ 6.73, $p=0.01$ ), with Hesketh Island individuals (489.8 \pm $241.5 \mathrm{~cm}, n=4$ individuals) being smaller than those at Jakolof Bay $(875.2 \pm 156.3 \mathrm{~cm}, n=5$ individuals $)$ and Outside Beach (798.0 $\pm 71.6 \mathrm{~cm}, n=5$ individuals; Fig. $6 \mathrm{~b})$. The new generation of Nereocystis sporophytes appeared in cleared plots by May and became reproductive in July. The overall smallest reproductive individual, $176 \mathrm{~cm}$, was measured in September at the Herring Islands. Though reproductive Nereocystis individuals were present at Outside Beach in May, only newly settled individuals were found in the harvested plots, so no reproductive individuals were measured for length during that sampling event. At least by March, a divergence between size frequency curves of reproductive and nonreproductive Nereocystis was evident over time before resembling one another in September (Fig. 6b). 


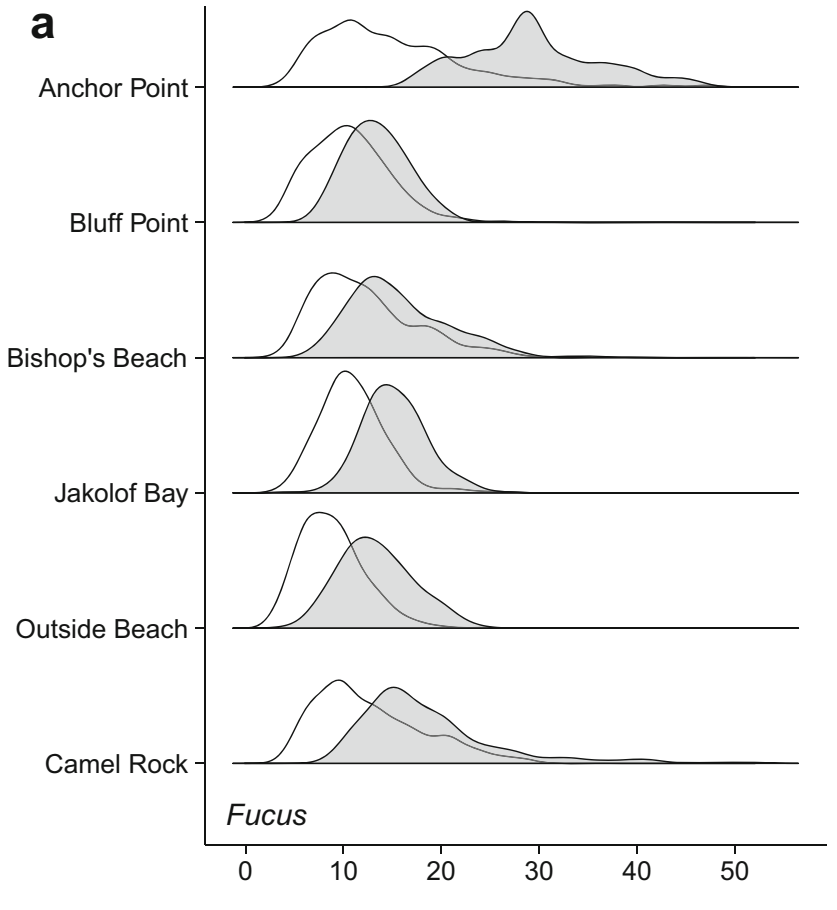

Fig. 6 Estimated size densities (kernel-smoothed) of non-reproductive (white) and reproductive (gray) individuals for a Fucus and b Nereocystis. Fucus sizes were similar over time and data were averaged

\section{Discussion}

Harvesters prefer collecting seaweeds during times of peak biomass for each targeted species. However, to sustainably harvest seaweeds, the timing of peak biomass should be balanced with reproductive timing (i.e., allowing mature plants to reproduce prior to harvest) and times of high regrowth (i.e., so that populations can rebound). This study demonstrates that to varying extents, seaweed harvesting in high latitudes may be sustainable if balanced with timing of reproduction and optimal regrowth.

\section{Fucus distichus}

While Fucus was found to be reproductive March through September (the entire study period), there were spatial differences in the size at reproductive maturity, with the minimum size of reproductive individuals being consistently larger at the semi-exposed site characterized by a higher percentage of boulder and sand substrate and lower tidal elevation. The results indicate that reproductive size in Fucus is spatially variable, and these size differences are accompanied by differences in standing crop and density. Individuals that became reproductive at a larger size were associated with less dense (and lower biomass) patches with slower regrowth. Wave exposure alone has previously been found to have only a small effect on intertidal Fucus morphology (Rice et al. 1985). In contrasting observations, where size decreased with increased

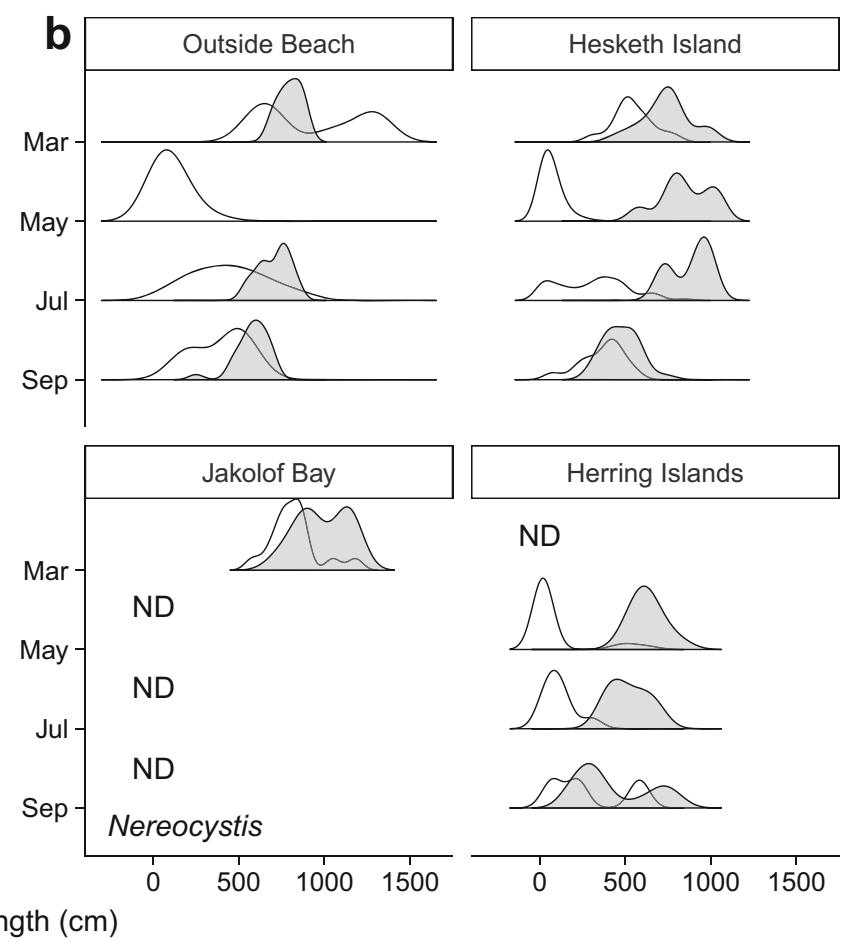

across months, while Nereocystis data were facetted by month due to more variability in size over time. $\mathrm{ND}=$ no data

wave exposure (Blanchette 1997), the presence of shifting substrate and extensive submergence at a negative tidal elevation might be contributing factors in determining density, biomass, and the size at which Fucus becomes reproductive. As such, soft sediment environments are least favorable for colonization of Fucus (Chapman and Fletcher 2002), which could partly explain the significantly lower biomass and fewer individuals found at Anchor Point. Disturbance induced by substrate instability may diminish the ability of Fucus recruits to settle. It has also been reported that Fucus decreased photosynthetic rates and growth when exposed to air for longer periods of time, not varying across tidal elevations (Chapman 1995; Williams and Dethier 2005). Fucus morphology is habitat-dependent (Sideman and Mathieson 1983a, 1983b; Sideman and Mathieson 1985), and our results documenting lower densities and larger individuals at lower tidal elevation corroborate that observation with one noteworthy exception. Anchor Point, the site with the lowest tidal elevation, had the lowest Fucus biomass and densities, but also some of the largest individuals. A possible explanation for this might be that these individuals are growing faster due to reduced competition, but the patch is also "thinned-out" in response to intertidal disturbances caused by wave action, substrate instability, and possibly grazing pressure (Knight and Parke 1950; Alstyne 1990).

Fucus standing crop increased from early to mid-summer, with peak standing crop mostly observed in July, before 
steadily declining till September. Late summer decline of Fucus growth has also been observed in other regions of the world (Sideman and Mathieson 1983a). A potential mechanism for this decline in Alaska is the increased frequency and magnitude of storms in Southcentral Alaska during late summer and fall that may dislodge seaweeds, reducing overall biomass.

Densities of Fucus appeared to influence the amount of biomass growth post-harvest. In the present study, an increase in Fucus density accompanied higher rebounded biomass. Sites with higher densities had more individuals less than $2 \mathrm{~cm}$ at the time of initial harvest that contributed to growth within the harvested plots. Fucus serratus, a close relative to F. distichus, also grew more slowly at higher densities (Creed et al. 1998). Individual growth rates were not measured in the present study. More post-harvest growth in higher-density Fucus patches was determined by biomass measurements. Individuals within less dense patches may have been growing faster due to less competition, but the number of individuals within high density patches was still growing fast enough to yield greater standing crop.

\section{Saccharina latissima}

Saccharina were not found to be reproductive until October. This observation is consistent with the reproductive timing of S. latissima in Norway (sori formation in October), another high-latitude region (Andersen et al. 2011; Andersen 2013). In this study, Saccharina responded with earlier reproduction at lower tidal elevations that had a lot of sand, and were under more frequent disturbance conditions (i.e., wave exposure).

Saccharina standing crop was spatially variable in this study. Standing crop increased from early to late summer, peaking in August at Anchor Point, while showing no such pattern at the other sites. Saccharina is often predominant where sand deposition has adverse effects on other kelp species (Spurkland and Iken 2011; Traiger and Konar 2018). At Anchor Point, it is possible that sand deposition may be contributing to the success of Saccharina over other intertidal seaweeds, as biomass can be significantly higher at exposed sites than sheltered sites (Peteiro and Freire 2013) and sediment deposits on blades can reduce the negative effects of ultraviolet radiation (Roleda et al. 2008; Roleda and Dethleff 2011). Other findings have shown proliferation of seaweeds as a response to environmental disturbances (Morand and Briand 1996); however, on a temporal scale, Saccharina has been shown to reduce frond elongation by July along coastlines of Northern Europe (Luning 1979; Andersen et al. 2011). In the present study, Saccharina generally decreased in biomass from June to October. This trend may be the result of individuals senescing in mid-summer, and reduced growth rates contributing to the decreased standing crop observed from June through October. Epiphytic growth may have also contributed to the reduced biomass of Saccharina after July, as epiphytic cover on kelp fronds is known to increase from June to September (Andersen et al. 2011; Andersen 2013), possibly resulting in brittle thalli and reduced access to light (Lambert et al. 1992). Although not quantified, epiphytic cover was observed in situ later in the summer.

Saccharina may grow best in lower intertidal and subtidal elevations, possibly explaining the greater relative success of Saccharina recovery at our low-elevation Anchor Point site. Since vertical distribution across tidal elevations and abundance of Saccharina are primarily influenced by grazing activity (Underwood and Jernakoff 1984), it is possible that invertebrate grazers are more successful in maintaining macroalgal recovery in tide pools less frequented by physical disturbances, such as at Bluff Point and Bishop's Beach. The lower tidal elevation of Saccharina at Anchor Point could facilitate such differences with the other sites.

A limitation of this study is that Saccharina was only sampled in intertidal tide pools and Saccharina harvesters might be collecting Saccharina lower on the beach during extreme low tides. If summer harvest is allowed, it would be outside of the winter reproductive window, but would still remove individuals that would potentially become reproductive the following winter. However, subtidal populations may be able to continue to seed other Saccharina populations.

\section{Nereocystis luetkeana}

Due to persisting overwintered adults, reproductive Nereocystis were found as early as March, which is unsurprising as overwintered adults are capable of regenerating blades with viable sori (Chenelot 2003). In other, lower-latitude regions (e.g., Puget Sound, Washington), first-year individuals of Nereocystis appear reproductive in May with the entire population completing its annual sporophyte life cycle by November of the same year (Maxell and Miller 1996). Though the present study observed reproductive Nereocystis in March, these individuals had extended their life cycle through the previous winter and into a second summer. These overwintered adults produced viable spores from spring onward, while the new generation produced viable spores as early as July. This finding is comparable to lower-latitude regions, such as British Columbia, where reproductive tissue forms in June (Foreman 1984).

A challenge for managers is what should be considered more important ecologically: safeguarding second-year plants or protecting present-year populations so that they can reproduce. Reproduction from new individuals would introduce more genetic mixing, while the second-year individuals could be supporting an already established microhabitat (Teagle et al. 2017). Another aspect to take into consideration is harvester interest. As harvesters target clean and smooth stipes for their products (e.g., pickles), it is likely that the new 
generation is preferred more than overwintered individuals coated with epiphytes. A problem with harvesting younger Nereocystis is that these new cohorts might contribute more to the overall reproductive success of the population. One study found that overwintered Nereocystis spore release had lower developmental success (i.e., slower rates of settlement and germination) than those released from the first-year individuals (Chenelot 2003). Assuming that overwintered Nereocystis adults produce viable spores that grow quickly enough to reach adult size by the end of summer, concern for removal of individuals from the reproductive pool in late summer is alleviated by the presence of these reproductive individuals in early summer.

Nereocystis did not exhibit significant differences in overall size across sites. However, there was an overall trend of less biomass and shorter stipes in late summer than in early summer. This trend can be explained by the loss of overwintered adults by September, with late summer measurements coming from the new generation of smaller reproductive adults possibly heading into their first winter. An increase in Nereocystis standing crop from early to late summer was apparent at just one site, while biomass at the other sites either remained steady throughout the summer or decreased over time. Nereocystis standing crop appeared to follow an oceanic gradient. Low salinity and high turbidity conditions have negative effects on Nereocystis growth (Schoch and Chenelot 2004; Deiman et al. 2012), and those conditions intensify toward inner Kachemak Bay. Accordingly, Nereocystis increased in biomass from the less exposed inner-bay sites (i.e., Jakolof Bay and Herring Islands) to the more exposed outer-bay sites (i.e., Outside Beach and Hesketh Island), suggesting they grow better in more oceanic conditions (this study), or that seasonal circulation patterns may be influencing their distribution around the bay (Schoch and Chenelot 2004). This suggests that the amount of Nereocystis biomass available for harvest should be greatest in more oceanic conditions, such as what was found on the southern, outer regions of Kachemak Bay, where sedimentation is low and estuarine conditions are reduced (Traiger and Konar 2018).

In this study, plots cleared of whole individuals were expected to have low post-harvest biomass relative to plots cleared of just the blades. However, this was not seen during most sampling events. Regrowth within the plots may have been from newly settled recruits or juveniles that grew to a harvestable size. Nereocystis has been reported to have stipe growth rates of $10.2 \mathrm{~cm}$ per day in Puget Sound, Washington (Maxell and Miller 1996) and up to $14.7 \mathrm{~cm}$ per day in Kachemak Bay (Chenelot 2003). When revisited after 2 months, stipes of some individuals that were removed of their blades had descended to the seafloor with degraded pneumatocysts absent of blades. The overwintered adults that were de-bladed in the present study may have already been stressed by aging, and the removal of their blades decreased their endurance near the end of their second year. Blade removal would also have decreased their surface area available for photosynthesizing and nutrient uptake. Faster growth of blades generally occurred at the more oceanic influenced site, with the exception of the more estuarine influenced site having high regrowth in early summer. It has been suggested that enhanced growth rates of kelp (Macrocystis pyrifera) in New Zealand is a function of the availability of nutrients and thinner diffusion boundary layers, reflected by higher wave action (Hepburn et al. 2007).

\section{Conclusions and Implications for Seaweed Management}

The results of this study have implications for managing the sustainable harvest of seaweed in high latitudes and will inform management plans for Southcentral Alaska and elsewhere. The present study suggests that July may be an optimal time to harvest Fucus, as this marks the end of the maximum reproductive period while having the most biomass available to harvesters. Harvests in August or later would occur outside periods of high productivity, but this is also when proportions of reproductive individuals (with targeted receptacles) decrease. Perhaps collection should be avoided during the reproductive period prior to July, as high reproductive contributions also occurring in May and June would help to buffer the effects of Fucus harvests during peak biomass in July. In contrast, harvesting intertidal Saccharina may be optimal and more desirable to harvesters before August, as this is when a biomass reduction becomes apparent, growth slows, and epiphytic cover escalates.

Harvesting Nereocystis in late summer might have negative effects on a population, as this would remove potentially overwintering reproductive adults. Mid-summer harvesting might be optimal, as this would allow overwintered adults to release spores in spring and would avoid removal of the new generation at the end of summer, promoting more consistent, rather than pulsed, recruitment throughout the year. An alternative strategy would be to harvest first-year Nereocystis at the end of summer after the first-year generation released their spores, leaving the overall region with a seed bank that can go into the next year to replenish the kelp population. Since the removal of all blades resulted in many individuals dying, perhaps specifying in regulation that only some blades of an individual thallus may be removed would decrease harvest mortality. This restriction would allow the individual to continue photosynthesizing and taking up nutrients as it recovered, though, in general, most Nereocystis are harvested for the stipe (just above the holdfast). Individuals harvested in this manner will not survive.

Regulations for harvesting seaweeds should account for the temporal and spatial variability of reproductive timing and biomass availability at the species level. Though species- 
level regulations can be challenging, it is done with sport and commercial fishing regulations in California, for example, where personal use harvest of Zostera spp., Phyllospadix spp., and Postelsia palmaeformis is prohibited (Sklar et al. 2020). The present study supports current harvesting restrictions in areas with limited reproduction, low biomass, and slow rebound. Such restrictions are especially advised in areas where coastline is easily accessible to residents. In addition, we recommend further ecosystem-wide studies in nonsubsistence areas that show potential for sustainable seaweed harvesting as a next step toward implementing regulations that allow harvesting. As wild seaweed stocks remain an important option for consumers, additional studies should consider not only the response of seaweeds to harvesting, but also the impact their removal may have on the ecosystem.

Acknowledgments We thank Katrin Iken and Glenn Hollowell for invaluable perspective and input and the many student volunteers who helped with sampling. Thank you to the National Oceanic and Atmospheric Administration/University of Alaska Fairbanks Kasitsna Bay Laboratory and Kachemak Bay National Estuarine Research Reserve staff for field and laboratory support.

Funding Information The research was sponsored by Alaska Sea Grant, University of Alaska Fairbanks (project R/101-12), with funds from the National Oceanic and Atmospheric Administration (grant NA18OAR4170078), and from the University of Alaska with funds appropriated by the state of Alaska. Additional support was provided by the Northern Gulf of Alaska Applied Research Award and the Robert and Kathleen Byrd Award.

Open Access This article is licensed under a Creative Commons Attribution 4.0 International License, which permits use, sharing, adaptation, distribution and reproduction in any medium or format, as long as you give appropriate credit to the original author(s) and the source, provide a link to the Creative Commons licence, and indicate if changes were made. The images or other third party material in this article are included in the article's Creative Commons licence, unless indicated otherwise in a credit line to the material. If material is not included in the article's Creative Commons licence and your intended use is not permitted by statutory regulation or exceeds the permitted use, you will need to obtain permission directly from the copyright holder. To view a copy of this licence, visit http://creativecommons.org/licenses/by/4.0/.

\section{References}

Alstyne, K.L. 1990. Effects of wounding by the herbivorous snails Littorina sitkana and L. scutulata (Mollusca) on growth and reproductions of the intertidal alga Fucus distichus (Phaeophyta). Journal of Phycology 26: 412-416.

Andersen, G.S. 2013. Patterns of Saccharina latissima recruitment. PLOS One 8: e81092. https://doi.org/10.1371/journal.pone. 0081092.

Andersen, G.S., H. Steen, H. Christie, S. Fredriksen, and F.E. Moy. 2011. Seasonal patterns of sporophyte growth, fertility, fouling, and mortality of Saccharina latissima in Skagerrak, Norway: Implications for forest recovery. Journal of Marine Biology 2011: $1-8$.

Ang, P.O. 1991. Natural dynamics of a Fucus distichus (Phaeophyceae, Fucales) population: Reproduction and recruitment. Marine Ecology Progress Series 78: 71-85.

Arbuckle, J., B. Beal, S. Brawley, S. Domizi, L. Mercer, D. Preston, G. Seaver, N. Sferra, P. Thayer, R. Ugarte, and C. Vonderweidt. 2014. Fishery management plan for rockweed (Ascophyllum nodosum). Maine: Maine Department of Marine Resources.

Blanchette, C.A. 1997. Size and survival of intertidal plants in response to wave action: A case study with Fucus gardneri. Ecology 78: 15631578 .

Carter, A.R., and R.J. Anderson. 1985. Regrowth after experimental harvesting of the agarophyte Gelidium pristoides (Gelidiales: Rhodophyta) in the Eastern Cape Province. South African Journal of Marine Science 3: 111-118.

Chapman, A.R.O. 1995. Functional ecology of fucoid algae: Twentythree years of progress. Phycologia 34: 1-22.

Chapman, A.S., and R.L. Fletcher. 2002. Differential effects of sediments on survival and growth of Fucus serratus embryos (Fucales, Phaeophyceae). Journal of Phycology 38: 894-903.

Chenelot, H. 2003. Factors affecting estuarine populations of Nereocystis luetkeana in Kachemak Bay, Alaska. Masters thesis, Fairbanks, AK: University of Alaska, Fairbanks.

Creed, J.C., J.M. Kain, and T.A. Norton. 1998. An experimental evaluation of density and plant size in two large brown seaweeds. Journal of Phycology 34: 39-52.

Deiman, M., K. Iken, and B. Konar. 2012. Susceptibility of Nereocystis luetkeana (Laminariales, Ochrophyta) and Eualaria fistulosa (Laminariales, Ochrophyta) spores to sedimentation. Algae 27: 115-123.

Dugan, J.E., and D.M. Hubbard. 2010. Loss of coastal strand habitat in Southern California: The role of beach grooming. Estuaries and Coasts 33: 67-77.

Dugan, J.E., D.M. Hubbard, M.D. McCrary, and M.O. Pierson. 2003. The response of macrofauna communities and shorebirds to macrophyte wrack subsidies on exposed sandy beaches of southern California. Estuarine, Coastal and Shelf Science 58: 25-40.

Eggertsen, L., C.E.L. Ferreira, L. Fontoura, N. Kautsky, M. Gullstrom, and C. Berkstrom. 2017. Seaweed beds support more juvenile reef fish than seagrass beds in a south-western Atlantic tropical seascape. Estuarine, Coastal and Shelf Science 196: 97-108.

Evans, L.V., J.A. Callow, and M.E. Callow. 1982. The biology and biochemistry of reproduction and early development in Fucus. Progress in Phycological Research 1: 67-110.

Foreman, R.E. 1984. Studies on Nereocystis growth in British Columbia, Canada. Hydrobiologia 116-117: 325-332.

Foster, M.S., and D.C. Barilotti. 1990. An approach to determining the ecological effects of seaweed harvesting: A summary. Hydrobiologia 204-205: 15-16.

Garcia-Esquivel, Z., and H. Felbeck. 2009. Comparative performance of juvenile red abalone, Haliotis rufescens, reared in laboratory with fresh kelp and balanced diets. Aquaculture Nutrition 15: 209-217.

Garza, D.A. 2012. Common edible seaweeds in the Gulf of Alaska. Alaska: University of Alaska Press.

Haegele, C.W., R.D. Humphreys, and A.S. Hourston. 1981. Distribution of eggs by depth and vegetation type in Pacific herring (Clupea harengus pallasi) spawnings in southern British Columbia. Canadian Journal of Fisheries and Aquatic Sciences 38: 381-386.

Hamilton, J., and B. Konar. 2007. Implications of substrate complexity and kelp variability for south-central Alaskan nearshore fish communities. Fishery Bulletin 105: 189-196.

Hepburn, C.D., J.D. Holborow, S.R. Wing, R.D. Frew, and C.L. Hurd. 2007. Exposure to waves enhances the growth rate and nitrogen 
status of the giant kelp Macrocystis pyrifera. Marine Ecology Progress Series 339: 99-108.

Hinojosa, I.A., M.M. Rivadeneira, and M. Thiel. 2011. Temporal and spatial distribution of floating objects in coastal waters of centralsouthern Chile and Patagonian fjords. Continental Shelf Research 31: 172-186.

Kimura, M.R., and H. Munehara. 2011. Spawning substrata are important for breeding habitat selection but do not determine premating reproductive isolation in three sympatric Hexagrammos species. Journal of Fish Biology 78 (1): 112-126.

Knight, M., and M. Parke. 1950. A biological study of Fucus vesiculosus L. and F. serratus L. The Journal of the Marine Biological Association of the United Kingdom 29: 439-514.

Krumhansl, K.A., and R.E. Scheibling. 2012. Production and fate of kelp detritus. Marine Ecology Progress Series 467: 281-302.

Krumhansl, K.A., J.N. Bergman, and A.K. Salomon. 2017. Assessing the ecosystem level consequences of a small-scale artisinal kelp fishery within the context of climate-change. Ecological Applications 27 (3): 799-813.

Lambert, W.J., P.S. Levin, and J. Berman. 1992. Changes in the structure of a New England (USA) kelp bed: The effects of an introduced species? Marine Ecology Progress Series 88: 303-307.

Levitt, G.J., R.J. Anderson, C.J.T. Boothroyd, and F.A. Kemp. 2002. The effects of kelp harvesting on its regrowth and the understorey benthic community at Danger Point, South Africa, and a new method of harvesting kelp fronds. South African Journal of Marine Science 24: $71-85$.

Lorentsen, S.H., K. Sjøtun, and D. Grémillet. 2010. Multi-trophic consequences of kelp harvest. Biological Conservation 143: 2054-2062.

Loureiro, R., C.M.M. Gachon, and C. Rebours. 2015. Seaweed cultivation: Potential and challenges of crop domestication at an unprecedented pace. New Phytologist 206 (2): 489-492.

Luning, K. 1979. Growth strategies of three Laminaria species (Phaeophyceae) inhabiting different depth zones in the sublittoral region of Helgoland (North Sea). Marine Ecology 1: 195-207.

Mafra, L.L., Jr., and S.R. Cunha. 2006. Sargassum cymosum (Phaeophyceae) in southern Brazil: Seasonality of biomass, recovery after harvest and alginate yield. Journal of Coastal Research 39: $1847-1852$.

Marine Scotland Directorate. 2016. Wild seaweed harvesting: Strategic environmental assessment environmental report. Edinburgh: Crown

Marinho, G.S., S.L. Holdt, M.J. Birkeland, and I. Angelidaki. 2015. Commercial cultivation and bioremediation potential of sugar kelp, Saccharina latissima, in Danish waters. Journal of Applied Phycology 27: 1963-1973.

Maxell, B.A., and K.A. Miller. 1996. Demographic studies of the annual kelps Nereocystis luetkeana and Costaria costata (Laminariales, Phaeophyta) in Puget Sound, Washington. Botanica Marina 39: 479-489.

Miller, R.J., L. Kui, A. Rassweiler, T. Lamy, D.C. Reed, and K.D. Lafferty. 2018. Giant kelp, Macrocystis pyrifera, increases faunal diversity through physical engineering. Proceedings of the Royal Society B 285: 20172571.

Monagail, M.M., L. Cornish, L. Morrison, R. Araujo, and A.T. Critchley. 2017. Sustainable harvesting of wild seaweed resources. European Journal of Phycology 52: 371-390.

Morand, P., and X. Briand. 1996. Excessive growth of macroalgae: A symptom of environmental disturbance. Botanica Marina 39: 491516.

Moss, B. 1967. The apical meristem of Fucus. New Phytologist 66: 6774.

Nelson, W.A., and A.M. Conroy. 1989. Effect of harvest method and timing on yield and regeneration of Karengo (Porphyra spp.) (Bangiales, Rhodophyta) in New Zealand. Journal of Applied Phycology 1: 277-283.
Nicholson, N.L. 1970. Field studies on the giant kelp Nereocystis. Journal of Phycology 6: 177-182.

Pearson, G.A., and S.H. Brawley. 1996. Reproductive ecology of Fucus distichus (Phaeophyceae): An intertidal alga with successful external fertilization. Marine Ecology Progress Series 143: 211-223.

Pereira, L. 2015. Edible seaweeds of the world. Boca Raton: CRC Press.

Peteiro, C., and Ó. Freire. 2013. Biomass yield and morphological features of the seaweed Saccharina latissima cultivated at two different sites in a coastal bay in the Atlantic coast of Spain. Journal of Applied Phycology 25: 205-213.

Peteiro, C., N. Sánchez, C. Dueñas-Liaño, and B. Martínez. 2014. Opensea cultivation by transplanting young fronds of the kelp Saccharina latissima. Journal of Applied Phycology 26: 519-528.

Redmond, S., L. Green, C. Yarish, J. Kim, and C. Neefus. 2014. New England seaweed culture handbook-nursery systems. Connecticut: Connecticut Sea Grant College Program CTSG-14-01.

Rice, E.L., T.J. Kenchington, and A.R.O. Chapman. 1985. Intraspecific geographic-morphological variation patterns in Fucus distichus and F. evanescens. Marine Biology 88: 207-215.

Roleda, M.Y., and D. Dethleff. 2011. Storm-generated sediment deposition on rocky shores: Simulating burial effects on the physiology and morphology of Saccharina latissima sporophytes. Marine Biology Research 7: 213-223.

Roleda, M.Y., K. Zacher, A. Wulff, D. Hanelt, and C. Wiencke. 2008. Susceptibility of spores of different ploidy levels from Antarctic Gigartina skottsbergii (Gigartinales, Rhodophyta) to ultraviolet radiation. Phycologia 47: 361-370.

Ruz, C.S., A.F. Muth, F. Tala, and A. Pérez-Matus. 2018. The herbivorous fish, Aplodactylus punctatus, as a potential facilitator of dispersal of kelp, Lessonia trabeculata, in Chile. Journal of Experimental Marine Biology and Ecology 500: 112-119.

Schoch, G.C., and H. Chenelot. 2004. The role of estuarine hydrodynamics in the distribution of kelp forests in Kachemak Bay, Alaska. Journal of Coastal Research 45: 179-194.

Sharma, S., L. Neves, J. Funderud, L.T. Mydland, M. Øverland, and S.J. Horn. 2018. Seasonal and depth variations in the chemical composition of cultivated Saccharina latissima. Algal Research 32: 107112.

Sideman, E.J., and A.C. Mathieson. 1983a. The growth, reproductive phenology, and longevity of non-tide-pool Fucus distichus (L.) Powell in New England. Journal of Experimental Marine Biology and Ecology 68: 111-127.

Sideman, E.J., and A.C. Mathieson. 1983b. Ecological and genecological distinctions of a high intertidal dwarf form of Fucus distichus (L.) Powell in New England. Journal of Experimental Marine Biology and Ecology 72: 171-188.

Sideman, E.J., and A.C. Mathieson. 1985. Morphological variation within and between natural populations of non-tide pool Fucus distichus (Phaeophyta) in New England. Journal of Phycology 21: 250-257.

Siméon, A., and C. Hervé. 2017. Isolation of Fucus serratus gametes and cultivation of the zygotes. Bio-Protocol 7. https://doi.org/10.21769/ BioProtoc. 2408 .

Sklar, E., J. Holster-Carmesin, R. Burns, P. Silva, S. Murray, and M. Miller-Henson. 2020. California Ocean Sport Fishing Regulations 2020-2021.

Smith, B.D. 1985. Recovery following expeirmental harvesting of Laminaria longicruris and L. digitata in southwestern Nova Scotia. Helgolfinder Meeresunters 39: 83-101.

Springer, Y.P., C. Hays, M. Carr, M. Mackey, and J. Bloeser. 2010. Ecology and management of the bull kelp Nereocystis luetkeana. Oceanography and Marine Biology: An Annual Review 48: 1-42.

Spurkland, T., and K. Iken. 2011. Kelp bed dynamics in estuarine environments in subarctic Alaska. Journal of Coastal Research 27: 133143. 
Steen, H., F.E. Moy, T. Bodvin, and V. Husa. 2016. Regrowth after kelp harvesting in Nord-Trøndelag, Norway. ICES Journal of Marine Science 73: 2708-2720.

Teagle, H., S.J. Hawkins, P.J. Moore, and D.A. Smale. 2017. The role of kelp species as biogenic habitat formers in coastal marine ecosystems. Journal of Experimental Marine Biology and Ecology 492: 81-98.

Traiger, S.B., and B. Konar. 2017. Supply and survival: Glacial melt imposes limitations at the kelp microscopic life stage. Botanica Marina 60: 603-617.

Traiger, S.B., and B. Konar. 2018. Mature and developing kelp bed community composition in a glacial estuary. Journal of Experimental Marine Biology and Ecology 501: 26-35.

Ugarte, R., and G. Sharp. 2012. Management and production of the brown algae Ascophyllum nodosum in the Canadian Maritimes. Journal of Applied Phycology 24: 409-416.

Umezu, Y., T. Onitsuka, T. Kawamura, and Y. Watanabe. 2017. Feeding of the short-spined sea urchin Strongylocentrotus intermedius on macroalgae and benthic animals. Fisheries Science 83: 221-233.

Underwood, A.J., and P. Jernakoff. 1984. The effects of tidal height, wave-exposure, seasonality and rock-pools on grazing and the distribution of intertidal macroalgae in New South Wales. Journal of Experimental Marine Biology and Ecology 75: 71-96.
Vandersea, M.W., S.R. Kibler, P.A. Tester, K. Holderied, D.E. Hondolero, K. Powell, S. Baird, A. Doroff, D. Dugan, and R.W. Litaker. 2018. Environmental factors influencing the distribution and abundance of Alexandrium catenella in Kachemak Bay and Lower Cook Inlet, Alaska. Harmful Algae 77: 81-92.

Vásquez, J.A., N. Piaget, and J.M.A. Vega. 2012. The Lessonia nigrescens fishery in northern Chile: "How you harvest is more important than how much you harvest.". Journal of Applied Phycology 24: 417-426.

Vea, J., and E. Ask. 2011. Creating a sustainable commercial harvest of Laminaria hyperborea, in Norway. Journal of Applied Phycology 23: 489-494.

Wentworth, C.K. 1922. A scale of grade and class terms for clastic sediments. The Journal of Geology 30: 377-392.

Wheeler, W.N. 1990. Kelp forests of British Columbia: A unique resource. British Columbia: Ministry of Agriculture and Fisheries, Aquaculture and Commercial Fisheries Branch.

White, W.L., and P. Wilson. 2015. World seaweed utilization. In Seaweed sustainability: Food and non-food applications, ed. B.K. Tiwari and D. Troy, 7-25. San Diego: Academic.

Williams, S.L., and M.N. Dethier. 2005. High and dry: Variation in net photosynthesis of the intertidal seaweed Fucus gardneri. Ecology 86: 2373-2379. 